\title{
EMERYCI I RENCIŚCI W POLSKIM SYSTEMIE UBEZPIECZEŃ SPOŁECZNYCH LAT 1944-1958: SYTUACJA MATERIALNA I STRATEGIE PRZETRWANIA
}

Starość, w tym związane z nią kwestie ubezpieczeń społecznych, w najnowszych dziejach Polski nie stały się jak dotąd tematem źródłowych, kompleksowych analiz. Tymczasem waga problemu, współcześnie coraz bardziej znaczącego, skłania do poszukiwania czynników mających wpływ na jego obecna postać.

W przedstawionym szkicu dokonana została analiza głównych czynników kształtujących sytuację materialną emerytów i rencistów ${ }^{1}$ od początków Polski Ludowej aż do 1958 r., tj. do momentu, w którym

${ }^{1} \mathrm{~W}$ związku z tym wyjaśnienia wymaga stosowanie określeń: renta i emerytura (oraz - co za tym idzie - rencista i emeryt). Jak twierdzi Wacław Szubert, już w latach tużpowojennych różnicowanie nazw „renta” i „emerytura” uległo pozornemu zatarciu. Pod względem zasad wymiaru renty starcze zostały zrównane całkowicie z rentami dla inwalidów, którzy stali się przedwcześnie niezdolnymi do zarobkowania. Jednakowy w obu przypadkach był też okres wyczekiwania i warunek ciagłości pracy, uzasadniający prawo do renty. Nie określano nawet świadczeń dla starców osobną nazwa; obie przewidziane kategorie nosiły (od przedwojnia) nazwę ustawową rent inwalidzkich. Starość była więc uznawana za domniemane inwalidztwo, choć zasada ta nie zawsze była konsekwentnie stosowana w polskim systemie ubezpieczeniowym; zob. W. Szubert, Niektóre zagadnienia rent starczych w świetle badań z 1948 r., „Przegląd Ubezpieczeń Społecznych” 1950, nr 4, s. 36-37. W języku powojennych aktów prawnych renty starcze po raz pierwszy zostały nazwane emeryturami w ustawie z $1968 \mathrm{r}$. Mając tego świadomość, ze względu na obowiązujący obecnie zwyczaj językowy, używam $\mathrm{w}$ tym tekście określenia emerytura zamiennie z pojęciem renta starcza; tam, gdzie pojawia się określenie renta, dotyczy ono nie tylko emerytur, ale również innych rodzajów rent (inwalidzkie, rodzinne, wypadkowe). Ponadto, z braku miejsca nie zajmuję się szczegółowymi kwestiami (choć czasami je wzmiankuję), dotyczącymi niektórych grup pobierających specyficzne typy świadczeń (renty zagraniczne, specjalne, dla żołnierzy wojska, funkcjonariuszy aparatu bezpieczeństwa, milicjantów, pracowników więziennictwa itp.). 
przeprowadzono ważną reformę systemu emerytalno-rentowego, będącą mało dotychczas znanym efektem procesów destalinizacyjnych. Według kryteriów przyjętych przez część specjalistów od systemów ubezpieczeń społecznych ten przedział czasowy obejmuje w całości okres ich odbudowy (1944-1949) oraz w części okres dominacji tendencji do centralizacji i koncentracji finansów ubezpieczeń w rękach państwa (1950-1968). W tym drugim (o czym szerzej piszę dalej) zniesiono istniejąca jeszcze do $1949 \mathrm{r}$. autonomię funduszów ubezpieczeniowych i włączono dochody i wydatki ubezpieczeń społecznych w pełnych kwotach do budżetu państwa ${ }^{2}$.

Dotychczas autorami opracowań naukowych na omawiany temat byli głównie specjaliści w zakresie polityki społecznej i socjolodzy. Ich badania grupy emerytów i rencistów rozpoczęły się jeszcze w latach czterdziestych $^{3}$, ale przerwał je stalinizm. Powrócili do nich w latach sześćdziesiątych.

Dzięki ustaleniom poczynionym przez historyków gospodarczych dysponujemy zarysem dziejów instytucji i systemu ubezpieczeń społecznych w Polsce, obejmującym również okres PRL ${ }^{4}$. Inni autorzy zajmowali się analizą powszechnego ubezpieczenia emerytalnego w zakresie ekonomicznym, finansowym i prawnym ${ }^{5}$. Brakuje jednak nadal prac zarówno na temat przesłanek i przemian polityki państwa w zakresie ubezpieczeń społecznych, jak też analizujacych realia życia emerytów i rencistów. W tej sytuacji poczynione poniżej uwagi są wstępną próba zarysowania tej problematyki, oparta głównie na kwerendach archiwalnych. Wynika z nich, że kwestie rentowo-emerytalne były przedmiotem zainteresowania ówczesnych władz zwłaszcza przy okazji kolejnych prób reformy systemu ubezpieczeń społecznych. Wtedy też wzrastała

${ }^{2}$ Ten okres nazywany jest niekiedy okresem dominacji koncepcji zabezpieczenia społecznego, kiedy to fundusze ubezpieczeniowe, pozbawione jakiejkolwiek autonomii, stały się częścią budżetu państwa. Takie stanowisko zob. C. Jackowiak, Kierunki rozwoju ubezpieczeń społecznych, w: Rozwój ubezpieczeń społecznych w Polsce, Warszawa 1991, s. 213. Jednak teza o zanikaniu ubezpieczenia społecznego i przekształcaniu się go w zabezpieczenie społeczne miała licznych oponentów i nie została w pełni zaakceptowana; zob. L. Mackiewicz-Golnik, Powszechne ubezpieczenie emerytalne. Aspekty ekonomiczne i problemy finansowania, Warszawa 1983, s. 100-101.

${ }^{3}$ W. Szubert, Badania nad społeczna rola rent ubezpieczeniowych, ,Studia i Materiały z Historii Ubezpieczeń Społecznych w Polsce” 1985, z. 3, s. 67-115; tenże, Niektóre zagadnienia rent starczych..., s. 36-40.

${ }^{4}$ Rozwój ubezpieczeń...

${ }^{5}$ M.in. W. Muszalski, Zatrudnienie a ubezpieczenie spoteczne, Warszawa 1992; L. Mackiewicz-Golnik, dz. cyt.; I. Jędrasik-Jankowska, Świadczenia z ubezpieczenia społecznego (chorobowe, rentowe i emerytalne), Warszawa 1989; taż, Ubezpieczenia spoteczne (chorobowe, rentowe i emerytalne). Zarys części ogólnej, Warszawa 1987. 
ilość dokumentacji na ten temat. Dzięki temu odpowiednie informacje można odnaleźć w przechowywanych w Archiwum Akt Nowych aktach KC PZPR, ministerstw (zwłaszcza zajmujących się praca, opieką społeczną i sprawami socjalnymi), Rady Państwa, Urzędu Rady Ministrów i związków emeryckich. Wiele niezwykle interesujących dokumentów zachowanych zostało w aktach Zakładu Ubezpieczeń Społecznych, przekazanych do AAN. Ciekawym źródłem dla tych badań stały się również biuletyny listów, wysyłanych przez emerytów i rencistów do warszawskiego centrum władzy. Ponadto owocna okazała się kwerenda prasowa, zwłaszcza dotycząca publicystyki z początków Polski Ludowej i z okresu odwilży politycznej lat 1953-1958.

\section{Kontekst demograficzny}

Wstępem do określenia głównych czynników kształtujących sytuację emerytów i rencistów w przyjętych cezurach czasowych musi być jednak opis uwarunkowań społeczno-demograficznych, wpływających na wielkość tej zbiorowości oraz systemu instytucjonalnego ubezpieczeń społecznych, w którym się znaleźli.

Sytuacja demograficzna Polski w tych latach była przede wszystkim skutkiem wojny i procesów przez nią wywołanych. W jej wyniku ludność Polski zmniejszyła się z ponad $35 \mathrm{mln}$ (w $1939 \mathrm{r}$.) do niespełna $24 \mathrm{mln}$ w 1946 r. Nastapiło pogłębienie nierównowagi płci. O ile w II Rzeczypospolitej proporcja mężczyzn do kobiet wynosiła (według szacunku dla 1939 r.) 48,8:51,2, to w 1946 r. $-45,8: 54,2^{6}$. Ponadto ofiara wojny padły przede wszystkim młode roczniki. W interesującym nas kontekście oznaczało to m.in., że o ile w okresie przedwojennym ubezpieczeni w wieku 23-32 lat stanowili 37,8\% ich ogółu, to w 1946 r. - 22,7\%. Spuścizna wojny była również milionowa armia wdów i sierot oraz inwalidów ${ }^{7}$. Kobiety samotne, matki wychowujące dzieci w niepełnych rodzinach ${ }^{8}$,

${ }^{6}$ K. Latuch, Straty demograficzne Polski w latach 1939-1945 (z prac nad weryfikacja oficjalnych szacunków), w: Polska 1939-1945. Straty osobowe i ofiary represji pod dwiema okupacjami, red. W. Materski, T. Szarota, Warszawa 2009, s. 40-41, tab. 1.

${ }^{7}$ M. Piatkowski, Społeczne ubezpieczenia rentowe $w$ pierwszym dziesięcioleciu Polski Ludowej, „Studia i Materiały z Historii Ubezpieczeń Społecznych w Polsce” 1985, z. 3, s. 63.

${ }^{8}$ Co ważne, tych dzieci było stosunkowo dużo. II wojna światowa bowiem co prawda spowodowała spadek wskaźnika liczby urodzeń, ale - w porównaniu chociażby z I wojna światowa - ta destrukcyjna faza rozwoju demograficznego przebiegała w sposób dużo bardziej łagodny; zob. H. Jędruszczak, Zatrudnienie a przemiany spoteczne $w$ Polsce $w$ latach 1944-1960, Wrocław 1972, s. 108-109. 
Tabela 1. Ludność w wieku poprodukcyjnym w Polsce 1946-1958

\begin{tabular}{|c|c|c|c|c|c|c|c|c|c|c|c|c|c|}
\hline \multirow[b]{3}{*}{ Lata } & \multirow[b]{3}{*}{$\begin{array}{l}\text { Ogółem } \\
\text { ludność } \\
\text { Polski } \\
\text { w tys. }\end{array}$} & \multicolumn{12}{|c|}{ W tym w wieku poprodukcyjnym } \\
\hline & & \multicolumn{2}{|c|}{ Razem } & \multicolumn{2}{|c|}{ Mężczyźni } & \multicolumn{2}{|c|}{ Kobiety } & \multicolumn{2}{|c|}{ W mieście razem } & \multicolumn{2}{|c|}{ Mężczyźni } & \multicolumn{2}{|c|}{ Kobiety } \\
\hline & & $\underset{3}{\dot{m}}$ & 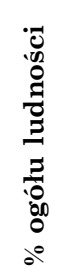 & $\begin{array}{l}\dot{\infty} \\
\hat{\omega} \\
3\end{array}$ & 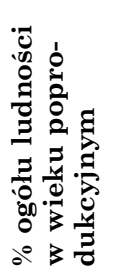 & $\begin{array}{l}\dot{\infty} \\
3 \\
3\end{array}$ & 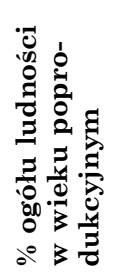 & $\sum_{\vec{D}}^{\dot{m}}$ & 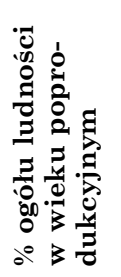 & $\begin{array}{l}\dot{\infty} \\
\overrightarrow{2} \\
3\end{array}$ & 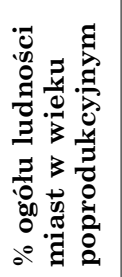 & $\begin{array}{l}\dot{m} \\
\overrightarrow{2} \\
3\end{array}$ & 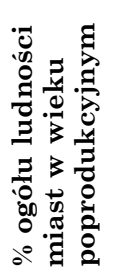 \\
\hline $1946^{\mathrm{a}}$ & 23930 & $2106^{b}$ & $8,8^{\mathrm{b}}$ & - & - & - & - & $682^{\mathrm{b}}$ & - & - & - & - & - \\
\hline 1948 & 24160 & 1636 & 6,8 & 501 & 30,6 & 1135 & 69,4 & - & - & - & - & - & - \\
\hline 1950 & 25035 & 1760 & 7,0 & 519 & 29,5 & 1241 & 70,5 & 631,1 & 35,9 & 169,1 & 26,8 & 462,0 & 73,2 \\
\hline 1951 & 25507 & 1790 & 7,0 & 530 & 29,6 & 1260 & 70,4 & - & - & - & - & - & - \\
\hline 1952 & 25999 & 1832 & 7,0 & 542 & 29,6 & 1290 & 70,4 & - & - & - & - & - & - \\
\hline 1953 & 26511 & 1886 & 7,1 & 561 & 29,7 & 1325 & 70,3 & - & - & - & - & - & - \\
\hline 1954 & 27012 & 1929 & 7,1 & 569 & 29,5 & 1360 & 70,5 & - & - & - & - & - & - \\
\hline 1955 & 27550 & 1997 & 7,2 & 583 & 29,2 & 1414 & 70,8 & 859,1 & 43,0 & 234,0 & 27,2 & 625,1 & 72,8 \\
\hline 1956 & 28080 & 2064 & 7,3 & 599 & 29,0 & 1465 & 71,0 & - & - & - & - & - & - \\
\hline 1957 & 28540 & 2128 & 7,5 & 615 & 29,0 & 1513 & 71,0 & - & - & - & - & - & - \\
\hline 1958 & 29000 & 2221 & 7,7 & 625 & 28,1 & 1596 & 71,9 & - & - & - & - & - & - \\
\hline $\begin{array}{l}\text { a według } \\
\text { b kobiety } \\
\text { Źródło: } \\
\text { s. } 20 \text {, ta } \\
\text { statystyc }\end{array}$ & $\begin{array}{l}\text { maryczne } \\
\text { nężczyźni } \\
\text { czenia wł } \\
12 ; \text { Roczn }\end{array}$ & $\begin{array}{l}\text { spisu } \\
\text { wieku } \\
\text { e na p }\end{array}$ & i w & $k d \epsilon$ & $\begin{array}{l}\text { iczny } \\
\text { Na, } 19\end{array}$ & $\begin{array}{l}-1968, \\
54-5\end{array}$ & rszaw & $\begin{array}{l}69 \text {, s. } 7 \\
\text { Roczni }\end{array}$ & $\begin{array}{l}\text { tabl. } \\
\text { tystyczn }\end{array}$ & $\begin{array}{l}\text { Rocznik } \\
\text { 950, Ws }\end{array}$ & $\begin{array}{l}\text { tystyczny } \\
\text { awa } 195\end{array}$ & $\begin{array}{l}957, \mathrm{Wa} \\
17, \mathrm{ta}\end{array}$ & $\begin{array}{l}\text { wa } 1957 \text {, } \\
\text {; Rocznik }\end{array}$ \\
\hline
\end{tabular}


szukały pracy ${ }^{9}$. W miarę upływu czasu ta nierównowaga płci zaczęła się zmniejszać $(1950-47,7: 53,3 ; 1960-48,4: 51,6)^{10}$.

Jak pokazuja szacunki zawarte w tabeli 1, wskaźnik procentowy ludności w wieku poprodukcyjnym (dla mężczyzn od 65., dla kobiet od 60. roku życia) stopniowo się zwiększał. Ponadto widać wyraźnie, że dysproporcja między płciami na korzyść kobiet wzrastała w sposób istotny w wieku poprodukcyjnym. Problem starości w Polsce, w tym szczególnie w przypadku miast - systemu ubezpieczeń i opieki społecznej, to przede wszystkim problem starych kobiet w mieście.

Zakończenie wojny rozpoczęło kompensacyjny cykl demograficzny, trwający mniej więcej do $1952 \mathrm{r}$. Charakteryzuje się on z jednej strony boomem małżeńskim, z drugiej - towarzyszącym mu boomem dziecięcym. W warunkach polskich oznaczało to, że - według szacunków demografów - w Polsce zawierano w latach 1945-1947 przypuszczalnie 14-15 małżeństw na 1000 osób, w latach następnych ten trend stopniowo wygasał i w latach 1954-1955 wskaźnik ów oscylował w okolicach 9,8-9,5\%o, a w 1965 r. wynosił 7,3\%. Dla porównania najwyższa wartość tego wskaźnika w II Rzeczypospolitej wyniosła 12,7\% (w 1919 r. $)^{11}$.

Podobna prawidłowość została zaobserwowana w przypadku urodzeń żywych: ich szczyt przypadł na 1952 r. (30,2 na 1000 osób), a następnie spadł do poziomu poniżej 20\% od 1962 r. Oznaczało to, że Polska w okresie apogeum boomu dziecięcego miała - obok prawdopodobnie Albanii - najwyższą stopę rodności w Europie ${ }^{12}$. Porównawcze badania tzw. obciążenia dziećmi (liczba dzieci w wieku 0-14 lat przypadająca na 100 osób dorosłych, tj. w wieku 15-64 lat) pokazały, że wskaźniki polskie, oscylujące wokół 46 (1950) i 59 (1960), były najwyższymi wśród europejskich państw bloku wschodniego i jednymi z najwyższych w porównaniu do krajów Europy Zachodniej (a w 1960 r. były wręcz najwyższe $)^{13}$.

Ten kontekst pozwala na precyzyjniejsze określenie bez wątpienia postępującego - w świetle dokonanych ustaleń - procesu starzenia się ludności. Okazuje się bowiem, że tzw. obciążenie starcami, czyli wskaźnik liczby osób w wieku poprodukcyjnym (od 60 lat w przypadku

${ }^{9}$ Zob. m.in. D. Jarosz, Polacy a stalinizm 1948-1956, Warszawa 2000, s. 120-123.

${ }^{10}$ Rocznik demograficzny 1945-1966, Warszawa 1968, s. 49, tabl. 13.

${ }^{11}$ E. Rosset, Oblicze demograficzne Polski Ludowej, Warszawa 1965, s. 14-15, 244-246.

12 Tamże, s. 15, 298.

${ }_{13}$ Tenże, Proporcja ludności nieprodukcyjnej jako problem ekonomiczny i społeczny, „Zeszyty Naukowe Uniwersytetu Łódzkiego” 1960, seria 1, z. 18, s. 65-71. 
kobiet i od $65 \mathrm{w}$ przypadku mężczyzn) przypadających na 100 osób w wieku produkcyjnym (15-64 lata mężczyźni, 15-59 lat kobiety), wynosił w Polsce w 1955 r. - 11,8, a w 1960 r. - 13,4. Odpowiednie wskaźniki w Europie Zachodniej kształtowały się w latach 1951-1961 na poziomie od ponad 20 (Austria, Wielka Brytania, Francja, Irlandia) do 14-15 (Grecja, Portugalia). Wśród krajów europejskich pozostajacych w sowieckiej strefie wpływów podobny wskaźnik uzyskiwała Bułgaria, a państwem o największej na świecie proporcji starców w stosunku do ludności w wieku produkcyjnym była NRD ${ }^{14}$. Ludność Polski w latach 1945-1958 starzała się więc, ale było to starzenie się w państwie demograficznie nadzwyczaj młodym.

\section{Powojenny system ubezpieczeń społecznych}

System ubezpieczeń społecznych po II wojnie światowej odradzał się $\mathrm{w}$ formach organizacyjnych charakterystycznych dla okresu przedwojennego.

Badacze tej problematyki podkreślaja, że w 1944 r. pod względem prawnym cechował się on brakiem powszechności ubezpieczenia, różnicami w uprawnieniach poszczególnych grup pracowniczych, istnieniem wielu odrębnych systemów rentowych, niskim poziomem rent, niezapewniajacym minimum utrzymania.

W Manifeście PKWN zapowiadano, że: „Natychmiast rozpocznie się odbudowa i rozbudowa instytucji Ubezpieczeń Społecznych na wypadek choroby i inwalidztwa, bezrobocia oraz ubezpieczenia na starość. Instytucje Ubezpieczeń Społecznych oparte będą na zasadach demokratycznego samorządu"15. Aby te zapowiedzi wypełnić, konieczna była rekonstrukcja systemu tych instytucji. Nie było to zadanie łatwe. Straty majątku ubezpieczeń społecznych, który przed wojna szacowano na 1,5 mld zł, wynosiły około 0,9 mld, czyli około $60 \%$. W chwili wyzwolenia spod okupacji niemieckiej na terenach byłego Generalnego Gubernatorstwa funkcjonował tylko ZUS i 17 ubezpieczalni, a na obszarach włączonych do Rzeszy aparat ten uległ całkowitej likwidacji.

Dekretem z 7 IX 1944 r. ustanowiono tymczasowe rady, tymczasowe zarządy i tymczasowe komisje rewizyjne ubezpieczalni społecznych jako organy samorządu. Powołano je z pewną zwłoka. W 1946 r. obradował pierwszy zjazd prezydiów tymczasowych zarządów ubezpieczalni i odbyło się pierwsze posiedzenie tymczasowej rady ZUS. Samorząd

\footnotetext{
${ }^{14}$ Tamże, s. 63-83.

${ }^{15}$ Manifest PKWN, Warszawa 1974, s. 22-23.
} 
systemu ubezpieczeń nigdy potem (w okresie do 1989 r.) nie zyskał tak daleko idących kompetencji jak wówczas. Wprowadzono również sądownictwo w sprawach ubezpieczeniowych: okręgowe sądy ubezpieczeń społecznych i Trybunał Ubezpieczeń Społecznych ${ }^{16}$.

Zadanie odbudowy aparatu ubezpieczeniowego powierzono sieci wysyłanych w teren pełnomocników. W efekcie tych działań już w maju 1945 r. funkcjonowały wszystkie dawne ubezpieczalnie społeczne, a pod koniec tego roku zaczęto budowę polskiego aparatu ubezpieczeniowego na tzw. Ziemiach Odzyskanych (w 1947 r. stworzono tam nowe ubezpieczalnie ${ }^{17}$ ). Nastapiło usunięcie przepisów niemieckiej ordynacji ubezpieczeniowej w zakresie ubezpieczenia emerytalnego i chorobowego na Górnym Ślacsku oraz ubezpieczenia emerytalnego pracowników rolnych w województwach poznańskim i pomorskim. Konsekwencją tych działań było powierzenie ZUS wykonywania tych ubezpieczeń, które dotychczas były sprawowane przez Zakład Ubezpieczeń na Wypadek Inwalidztwa w Chorzowie. W ten sposób osiagnnięto jednolite ustawodawstwo w zakresie ubezpieczeń rentowych.

W tym pierwszym okresie istniała samodzielność finansowa systemu ubezpieczeń społecznych. Zachowana została odrębność składki akumulującej pięciu samodzielnych funduszów ubezpieczeniowych: 1) ubezpieczenia emerytalnego robotników, 2) ubezpieczenia emerytalnego pracowników umysłowych, 3) ubezpieczenia od wypadków i chorób zawodowych, 4) ogólnego funduszu na wypadek choroby i macierzyństwa, 5) wprowadzonego od 1948 r. ubezpieczenia rodzinnego ${ }^{18}$.

Rozporządzeniem ministra pracy i opieki społecznej z 13 VI 1946 r. (Dz. U., nr 26, poz. 172) ustalono stawki kwotowe rent, dla pracowników umysłowych na poziomie nieco wyższym niż dla fizycznych. W nowym systemie pracownicy zostali zwolnieni od ponoszenia kosztów ubezpieczenia przez przerzucenie obowiązku uiszczenia całości składki na pracodawcę (dokonał tego już dekret z 29 IX 1945 r. o uiszczaniu przez pracodawców całości składek na ubezpieczenia społeczne i na fundusz pracy, Dz. U., nr 43, poz. 240) ${ }^{19}$.

\footnotetext{
${ }^{16}$ C. Jackowiak, dz. cyt., s. 215-216.

${ }^{17}$ Tamże, s. 215-216; M. Piątkowski, dz. cyt., s. 214; W. Cieślak, J. Krasoń, Ksztattowanie się systemu ubezpieczenia społecznego na Pomorzu Zachodnim 1945-1946, „Studia i Materiały z Historii Ubezpieczeń Społecznych w Polsce” 1989, t. 7, s. 83-92; W. Bujarski, Organizacja ubezpieczeń społecznych na Ziemiach Odzyskanych, „Przegląd Ubezpieczeń Społecznych” 1948, z. 7 (cały zeszyt poświęcony został różnym aspektom ubezpieczeń na tym obszarze).

${ }^{18}$ C. Jackowiak, dz. cyt., s. 220.

${ }_{19}$ Tamże.
} 
Ponadto w okresie tużpowojennym nastapiło znaczne złagodzenie warunków wymaganych do uzyskania prawa do świadczeń w stosunku do osób, u których zapotrzebowanie na świadczenia powstało w następstwie wojny (skrócenie czasu wyczekiwania w przypadkach, gdy inwalidztwo nastapiło na skutek działań wojennych, uwzględnienie wszystkich przerw w ubezpieczeniu, które zaistniały w czasie trwania działań wojennych, uznanie za równorzędne z okresami ubezpieczenia okresów pracy przymusowej w Niemczech oraz wypadków zaistniałych w czasie tej pracy na równi $\mathrm{z}$ wypadkami w zatrudnieniu).

Najważniejszym osiagnięciem powojennego systemu ubezpieczeń społecznych, podkreślanym $\mathrm{w}$ tekstach programowych na ten temat, miało być to, że stanowiły tylko jedno $\mathrm{z}$ wielu narządzi (obok akcji socjalnej, mieszkaniowej itp.), które miały zapewnić „klasie pracowniczej, poza jej zarobkami, poważne świadczenia, zaspokajające jej materialne potrzeby i wpływające na poprawę warunków jej bytu”. Ta przewaga powojennych rozwiązań miała polegać na rozszerzeniu zasięgu osobowego i rzeczowego ubezpieczeń oraz udzielaniu ich według tych samych zasad wymiaru dla wszystkich pracowników i ich rodzin, bez względu na charakter ich zajęcia ${ }^{20}$. „Ubezpieczeniowy podział klasy pracowniczej” na pracowników umysłowych i robotników miał być ,jawnym i typowym przykładem wykorzystywania ubezpieczeń przez państwa kapitalistyczne dla rozbijania jedności robotniczej”. Zgodnie ze stalinowską wykładnią, należało doprowadzić do zlikwidowania „białych plam na mapie ubezpieczeniowej" ${ }^{21}$.

Dla realizacji tych zasad już 8 I 1946 r. wydany został dekret o objęciu rencistów bezpłatna pomoca leczniczą (szczegółowe zasady ustaliło Ministerstwo Zdrowia w marcu 1947 r. $)^{22}$. Od 1 III 1947 r. objęto ubezpieczeniem na wypadek choroby pracowników rolnych zatrudnionych w gospodarstwach powyżej 30 ha, a od 1 III 1948 r. - pozostałych pracowników rolnych, zapewniając im ochronę lecznicza. Powołano do życia ubezpieczenie rodzinne (dekret z 28 X 1947 r., Dz. U., nr 66, poz. 414).

Stopniowo wzrastała liczba osób pobierających renty. W 1945 r. było ich 174 tys., a na koniec 1948 r. - 590 tys. W drugiej połowie 1948 r. rent wypłacano już więcej niż przed wojna. W czerwcu 1948 r. liczba tzw. rent płynnych długoterminowych wyniosła 499,7 tys., w tym od

${ }^{20}$ R. Garlicki, Ubezpieczenia społeczne jako czynnik poprawy bytu mas pracujacych, „Praca i Opieka Społeczna” 1951, nr 2, s. 30; Osiagnięcia powojenne klasy robotniczej, tamże, s. 41-42.

${ }^{21}$ R.G., Budowa jednolitego ubezpieczenia społecznego powiazanego $z$ socjalistycznym stosunkiem pracy, „Przegląd Ubezpieczeń Społecznych” 1952, nr 7, s. 201.

${ }^{22}$ H. Pławucka, Świadczenia emerytalne i rentowe, w: Rozwój ubezpieczeń..., s. 371. 
wypadków - 82,1 tys., emerytalnych robotników - 375 tys., pracowników umysłowych $-42,6$ tys. ${ }^{23}$

W kwietniu $1947 \mathrm{r}$. podwyższono uposażenia emerytalne o 100\%, aczkolwiek nie zmieniono zasad ich wypłacania. Zachowano zasadę rent jednolitych, bez względu na staż pracy i wysokość zarobku ubezpieczonego. Utrzymano ją do początku 1949 r., kiedy wprowadzono nowe zasady ustalania wysokości renty (rozporządzenie Rady Ministrów z 8 III 1949 r., Dz. U., nr 18, poz. 120). Renciści, którzy pracowali po wyzwoleniu spod okupacji hitlerowskiej co najmniej 18 miesięcy, nabyli prawo do obliczenia renty na podstawie osiaganych $\mathrm{w}$ ciagu ostatnich sześciu miesięcy zatrudnienia zarobków. Wysokość takiej renty była równa dla pracowników fizycznych i umysłowych, i uzależniona od wysokości osiaganego uposażenia ${ }^{24}$.

Ustawa z 1 III 1949 r. dokonała zrównania uprawnień wdów po pracownikach fizycznych i umysłowych (prawo do renty nabywały wdowy niezdolne do zarobkowania, które ukończyły 55. rok życia lub wychowywały małoletnie dzieci). Rozszerzono również prawo do dodatku z tytułu bezradności na wszystkich rencistów oraz stworzono jednolite dla wszystkich rodzajów ubezpieczeń rentowych zasady przyznawania zasiłków pogrzebowych.

Tymczasowa Rada ZUS uchwała z 18 XII 1947 r. stworzyła tzw. świadczenia wyjątkowe, które mogły być przyznawane uznaniowo pracownikom niespełniającym ustawowych warunków do przyznania renty, jeżeli odmowa renty byłaby „społecznie niesłuszna”.

Etatyzacja życia organizacyjnego w okresie stalinizmu nie ominęła systemu ubezpieczeń, które zostały włączone w ramy planu państwowego od 1949 r. Ustawa z 1 III 1949 r. oraz rozporządzeniem Rady Ministrów z 8 III 1949 r. zniesiono odrębność poszczególnych funduszy ubezpieczeń, tworząc jeden. Wysokość składki uzależniona została od sektora, w którym pracował ubezpieczony ${ }^{25}$.

Ustawa z 1 VII 1949 r. (Dz. U., nr 42, poz. 304) ustalono nowe zasady zaopatrzeń emerytalnych funkcjonariuszy państwowych i zawodowych wojskowych oraz pozostałych po nich wdów, szeregując m.in. do grup uposażenia obowiązujących od 1 I 1949 r. emerytów, którzy nabyli prawo do zaopatrzenia emerytalnego z tytułu służby pełnionej wcześniej. Ustalono również nową wysokość świadczeń emerytalnych.

${ }^{23}$ W. Szubert, Badania..., s. 72.

${ }^{24}$ H. Pławucka, dz. cyt., s. 374. Jak twierdzi cytowana autorka, to wówczas nastapił pierwszy po wojnie podział rencistów na dwa „portfele”.

${ }^{25}$ C. Jackowiak, dz. cyt., s. 221-222; Uposażenia emerytalne rencistów, „Głos Emeryta i Rencisty" (Łódź) 1949, nr 1. 
Od 1950 r. możemy mówić o dominacji koncepcji zabezpieczenia społecznego w polskim systemie ubezpieczeń społecznych, trwającej do 1968 r. Rozpoczęło ją przyjęcie 20 VII 1950 r. ustawy o ZUS. Zniesiona została odrębność funduszu ubezpieczeniowego, a budżet ubezpieczeń został włączony do budżetu państwa; ZUS stał się jego wykonawca. Spod jego kompetencji wyłączono lecznictwo, które tą ustawą powierzono Zakładowi Lecznictwa Pracowniczego (ZLP, zniesiony 1 I 1952 r.). Zlikwidowane zostały również ubezpieczalnie społeczne. Struktura ZUS składała się odtąd z trzech szczebli: oddziałów wojewódzkich i obwodowych oraz centrali ${ }^{26}$.

W ramach ujednolicania systemu i niwelacji różnic, mających długa tradycję, sięgajaca nawet okresu sprzed I wojny światowej, w $1950 \mathrm{r}$. ZUS przeją m.in. wypłatę emerytur byłych izb przemysłowo-handlowych, prowizji byłych robotników żup solnych, rent wypłacanych przez banki i instytucje kredytowe, dla robotników przemysłu cukrowniczego, byłych pracowników Państwowego Zakładu Ubezpieczeń Wzajemnych, zaopatrzeń emerytalnych pracowników byłych monopoli: spirytusowego i tytoniowego oraz świadczeń dodatkowego ubezpieczenia bratniego górników (zlikwidowano Spółkę Bracką w Tarnowskich Górach i Kasę Bratnią Górników w Sosnowcu ${ }^{27}$ ).

Ustawą z 29 XII 1951 r. włączono również do ZUS Państwowy Zakład Emerytalny, który wypłacał zaopatrzenia etatowym funkcjonariuszom państwowym i wojskowym zawodowym, a także byłym skazańcom politycznym, uczestnikom walk o niepodległość, a od 14 VIII 1951 r. - również zaopatrzenia emerytalne pracownikom byłego Związku Samorządu Terytorialnego.

Zgodnie z okólnikiem ZUS nr 101 z 12 V 1951 r. podstawa przyznania świadczeń stał się udowodniony okres zatrudnienia bez względu na to, czy pracownik był zgłoszony do ubezpieczenia i czy opłacono za niego składki. Nastapiło całkowite uniezależnienie od siebie prawa do świadczenia i obowiazku uiszczenia składek, co nadawało świadczeniom rentowym charakter uprawnień związanych ze stosunkiem pracy. Podstawą wymiaru stał się globalny fundusz płac, a nie indywidualne zarobki pracowników. Składki stały się więc instrumentem nieróżniącym się niczym od podatków.

Zasadę, że wysokość świadczeń nie jest uzależniona od stażu pracy ani od rodzaju wykonywanego zatrudnienia uchylano tylko wyjątkowo

${ }^{26}$ E. Borowczyk, Organizacja ubezpieczeń społecznych, w: Rozwój ubezpieczeń..., s. $240-242$.

${ }^{27}$ C. Jackowiak, dz. cyt., s. 221; L. Mackiewicz-Golnik, dz. cyt., s. 52-101. 
wówczas, gdy wymagały tego ważne względy państwowe. Stało się tak w przypadku górników. Na mocy uchwał: Rady Ministrów z 30 XI 1949 r. (Karta górnika) ${ }^{28}$ i 3 III 1950 r. ${ }^{29}$ oraz Prezydium Rządu z 10 I $1951^{30}$ i 8 XII $1951 \mathrm{r}^{31}$ otrzymywali oni (zarówno ci pracujacych w kopalniach węgla kamiennego, jak i w kopalniach innych surowców) świadczenia zróżnicowane w zależności od zajmowanego stanowiska oraz znacznie wyższe od przeciętnych. W ideologicznych uzasadnieniach tych decyzji wskazywano, że polskie ubezpieczenie rentowe niedostatecznie uzależniało wysokość rent od ilości i jakości pracy. System świadczeń rzeczowych na podstawie Karty górnika miał to zmienić. „W ten sposób pisano - zapoczątkowana została także niezbędna przebudowa systemu świadczeń rentowych dla ogółu robotników i pracowników, przebudowa, która u podstaw wymiaru renty położyć musi zasadę wartościowania pracy rencisty" 32 . Państwowy system zaopatrzeń emerytalnych miał zapewniać wyższe świadczenia „nie tym spośród ubezpieczonych, którzy formalnie przynależą do jakiejś uprzywilejowanej grupy, lecz tym, których praca jest szczególnie ciężka i szczególnie cenna dla rozwoju gospodarki i kultury narodowej”33. Karta górnika, podobnie jak uchwała Prezydium Rządu z 1 XII 1951 r. (tzw. Karta stoczniowca) były traktowane jako realizacja zapisanej w Konstytucji PRL zasady „każdemu według jego pracy”34.

Zgodnie z ideologia i polityka państwa stalinowskiego w $1953 \mathrm{r}$. nastapiło objęcie ubezpieczeniem emerytalnym robotników rolnych na obszarze całego państwa.

${ }^{28}$ Uchwała Rady Ministrów z dnia 30 XI 1949 r. w sprawie szczególnych przywilejów dla górników w górnictwie węglowych, „Monitor Polski”, nr A-100, poz. 1175.

${ }^{29}$ Uchwała Rady Ministrów w sprawie przywilejów dla górników w górnictwie rud, kruszców i kopalń glinki ogniotrwałej, „Monitor Polski”, nr A-29, poz. 336.

${ }^{30}$ Uchwała nr 15 Prezydium Rządu z 10 I 1951 r. w sprawie świadczeń emerytalnych dla górników, zatrudnionych pod ziemia, „Monitor Polski” nr 5, poz. 64.

${ }^{31}$ Uchwała nr 834 Prezydium Rządu z 8 XII 1951 r. w sprawie przywilejów dla górników zatrudnionych w podziemnych kopalniach soli kamiennej, „Monitor Polski”, nr A-102, poz. 1484.

${ }^{32}$ F. Woźniczka, Przywileje rentowe za wysoki wkład pracy. Rozwój ubezpieczenia emerytalnego górników w Polsce Ludowej, „Przegląd Ubezpieczeń Społecznych” 1954, nr 7-8, s. 199.

${ }^{33}$ J. Piotrowski, Realizacja zapowiedzi wielkiego Manifestu, „Przegląd Ubezpieczeń Społecznych" 1954, nr 7-8, s. 185.

${ }^{34}$ Zob. Uchwała nr 826 Prezydium Rządu z 1 XII 1951 r. w sprawie środków zmierzających do zapewnienia rozwoju przemysłu okrętowego (A. Kochański, Polska 1944-1989. Informator historyczny, t. 1, Warszawa 1996, s. 413); L. Frąckiewicz, Karta praw człowieka starego, Warszawa 1985, s. 10-16; Karta Stoczniowca, „Przegląd Ubezpieczeń Społecznych” 1952, nr 2, s. 41 
Podwyżka świadczeń rentowych z ubezpieczenia powszechnego, związana z podwyżką cen dokonaną w styczniu 1953 r., nie wpłynęła w istotny sposób na zmianę położenia materialnego emerytów. Nadal wysokość świadczeń nie była uzależniona od stażu pracy ani od rodzaju wykonywanego zatrudnienia ${ }^{35}$.

Obowiąujący w stalinizmie system świadczeń charakteryzował się tym, że co prawda objęta nim była coraz liczniejsza grupa ludności (w 1938 r. - 2357 tys. osób, tj. 6,8\% populacji, a w 1952 r. - odpowiednio 5581 tys. i $22,1 \%$ ), ale wysokość najważniejszych z nich - rent (w tym emerytur) oscylowała wokół minimum egzystencji, co stawiało pobierających przed koniecznością obrania strategii przeżycia w tych trudnych warunkach ${ }^{36}$. Dochody z rent nie mogły bowiem stanowić źródła utrzymania ${ }^{37}$. Nie udało się odnaleźć jednoznacznych przekazów, które odpowiadałyby na pytanie, na ile była to polityka świadoma, wynikająca z przeświadczenia, że emeryci to ludzie nieproduktywni, nieprzyczyniający się do realizacji planów gospodarczych i z tego powodu nie należy podwyższać im świadczeńn ${ }^{38}$.

To dostosowywanie systemu ubezpieczeń do aktualnej linii polityczno-ideologicznej oraz celów ekonomicznych partii/państwa widać

${ }^{35}$ Zob. m.in. Wysokość rent $i$ zaopatrzeń z ubezpieczenia powszechnego. Rozporzadzenie Rady Ministrów z 17 stycznia 1953 (Dz.U. nr 8, poz. 20), „Przegląd Ubezpieczeń Społecznych" 1953, nr 2, s. 39-40.

${ }^{36}$ M. Piątkowski, dz. cyt., s. 49-60.

${ }^{37}$ M. Winiewski, Rozwój zaopatrzenia emerytalnego w Polsce, „Praca i Zabezpieczenie Społeczne" 1968, nr 4, s. 1.

${ }^{38}$ Pewną poszlaka świadcząca o stosunku najwyższych władz do kwestii emerytur jest następujący fragment z dziennika Jana Józefa Lipskiego, który pod datą 28 XII 1956 r., komentując spotkanie przedwyborcze z udziałem Leona Chajna, pisał, że ten ostatni był świadkiem dyskusji najwyższych władz partyjnych w sprawie podwyższenia rent i emerytur. Bierut miał się temu sprzeciwiać, „motywując to tym, że emeryci sa to ludzie nieproduktywni, niebiorący udziału w realizacji Planu 6-letniego, wiec nie jest wskazane podwyższenie emerytur"; zob. J.J. Lipski, Dzienniki 1954-1957, przedm. A. Friszke, oprac. i przyp. Ł. Garbal, Warszawa 2010, s. 209-210. Inna ważna poszlaka, dotycząca polityki niskich uposażeń, pochodzi z akt Sekcji Ubezpieczeń Wydziału Ekonomicznego KC PPR. Jej przewodniczący we wrześniu 1948 r. w trakcie obrad tego gremium twierdził, że „to było czynione pod katem widzenia produktywizacji możliwe jak największych mas społecznych, wciagania ludzi do pracy produkcyjnej”. Jednocześnie miał świadomość, że „nikła wysokość rent właściwie burzy cały system ubezpieczeń i cały sens, dla którego to ubezpieczenie istnieje. Przede wszystkiem jeżeli renta jest bardzo niska, jest niemożliwe wyciagniecie z warsztatów pracy ludzi niedołężnych, bo ich się skazuje na głód. Z drugiej strony czyim są ciężarem? Tej samej klasy pracującej. To są krewni tych samych pracujących robotników, którzy z konieczności ze swoich zarobków muszą ich utrzymywać”; zob. Archiwum Akt Nowych (dalej: AAN), O reformie ubezpieczeń społecznych. Referat wygłoszony 30 IX 1948 r. na posiedzeniu Sekcji Ubezpieczeń Wydziału Ekonomicznego KC PPR, k. 28. 
w wielu rozwiązaniach szczegółowych. Warto wskazać na przynajmniej niektóre $\mathrm{z}$ nich.

Jako wyraz troski o tych, którzy zasłużyli się w tworzeniu zrębów nowego ustroju, interpretowano wprowadzenie 13 XI $1945 \mathrm{r}$. dekretu o zasiłkach i pomocy dla wdów i sierot po ofiarach wrogów demokratycznego ustroju państwa (Dz. U., nr 51, poz. 294). Zapewniał on tej kategorii osób stałe zasiłki wysokości od 40 do 60\% uposażenia urzędnika państwowego X klasy uposażenia oraz bezpłatną pomoc lekarska, uprawnienia $\mathrm{w}$ zakresie przyjmowania do pracy, otrzymywaniu kartek żywnościowych, przydziałów mieszkaniowych i w osadnictwie na tzw. Ziemiach Odzyskanych ${ }^{39}$.

Podobne uprawnienia zapewniała ustawa z 23 VII 1945 r. o zasiłkach i pomocy dla osób pozostałych po uczestnikach ruchu podziemnego i partyzanckiego, poległych w walce o wyzwolenie Polski spod najazdu hitlerowskiego (Dz. U., nr 30, poz. 180). O ich przyznaniu decydowały specjalne komisje kwalifikacyjne ${ }^{40}$.

Wreszcie, specjalne akty normatywne, wydawane od 1946 r., regulowały zaopatrzenie emerytalne dla tych, którzy stali na straży systemu władzy: funkcjonariuszy bezpieczeństwa publicznego, Milicji Obywatelskiej, Straży Więziennej, żołnierzy Wojska Polskiego i Wojsk Wewnętrznych ${ }^{41}$. Ich świadczenia emerytalno-rentowe były oparte

${ }^{39}$ Wydatki na ten cel wynosiły: 1946 r. - 3953222 zł, w $1947-28630238$ zł, 1948 - 65070954 zł, a liczba pobierających zasiłki: 31 XII 1946 - 516 osób, 31 XII 1947 1935, 31 XII 1948 - 3368 osób; zob. AAN, Kancelaria Cywilna Prezydenta RP i Kancelaria Rady Państwa (dalej: KCP), sygn. 75, Wydatki na zasiłkobiorców ofiar wrogów ustroju demokratycznego wypłacone od 1946 do 30 IX 1949 r., k. nlb.; AAN, Komitet Centralny PZPR (dalej: KC PZPR), sygn. 237/XIV-374, mkf B-58689, Notatka dotycząca zaopatrzeń ofiar wrogów demokratycznego ustroju Polski, k. 48. Na początku 1957 r. tym zaopatrzeniem było objętych około 30 inwalidów i 4000 rodzin. Ta mała liczba świadczeniobiorców wynikała z faktu, że większość osób, którym przysługiwało to świadczenie, otrzymywała zaopatrzenie z powszechnego systemu zaopatrzeniowego $\mathrm{z}$ tytułu zatrudnienia lub osiagało w rozumieniu dekretu wystarczajace środki egzystencji, co powodowało zawieszenie jego wypłaty; zob. J. Boczek, Zaopatrzenie ofiar wrogów demokratycznego ustroju Polski, „Przegląd Ubezpieczeń Społecznych” 1957, nr 3, s. 86-87.

${ }^{40}$ Wydatki na realizacje tej ustawy wyniosły w 1946 r. - 32801439 zł, w 1947 363874316 zł, a w 1948 - 699839933 zł, natomiast liczba osób pobierajaccych zasiłki: 31 XII 1946 - 4546, 31 XII 1947 - 19 964, 31 XII 1948 - 34168 osób; zob. AAN, KCP, sygn. 75, Wydatki na pozostałych po uczestnikach ruchu podziemnego i partyzanckiego wypłacone przez PZE od 1946 do 30 IX 1949 r., k. nlb.

${ }^{41}$ Zob. m.in. instrukcja tymczasowa ministra bezpieczeństwa publicznego z 17 XII 1946 r. o warunkach i trybie przyznawania uposażenia emerytalnego i odszkodowań dla funkcjonariuszy bezpieczeństwa publicznego, milicji Obywatelskiej, Straży Więziennej oraz ich rodzin; zarządzenie ministra bezpieczeństwa publicznego $\mathrm{nr} 15$ 
nie na składkach, ale miały charakter odszkodowawczy i zaopatrzeniowy ${ }^{42}$.

Z drugiej strony system ubezpieczeń miał „karać” tych, którzy z punktu widzenia władz państwa byli uznawani za jego wrogów czy chociażby „element niepożądany”. Z tego powodu w okresie stalinowskim składki ubezpieczeniowe stały się elementem pokazującym zróżnicowanie stosunku władz do różnych podmiotów gospodarczych ze względu na typ własności. Zaprzestano bowiem wówczas nie tylko - jak wzmiankowałem - obliczania składki od indywidualnych wynagrodzeń poszczególnych pracowników i przyjęto zasadę naliczania jej od funduszu płac, ale również zdecydowano, że w zakładach uspołecznionych będzie ona wynosić $15,5 \%$, a w sektorze prywatnym (od 1 I 1949 r.) $30 \%$ od faktycznie wypłacanych zarobków, bez prawa potrącenia jakiejkolwiek części składki od zarobku pracownika ${ }^{43}$. Podwyżki składek dla przedsiębiorstw prywatnych były zresztą stosowane już wcześniej ${ }^{44}$. Najwyższa Izba Kontroli ustaliła, że stosunek procentowy zaległości do ogólnej sumy przypisu sektora prywatnego w okresie styczeń-maj 1950 r. wynosił 46\% (2 792860876 zł $)^{45}$.

Dyskryminacyjny charakter miały przepisy ubezpieczeniowe dotyczące osób, które na podstawie dekretu z 13 IX 1946 r. o wyłączeniu ze społeczeństwa polskiego osób narodowości niemieckiej zostały pozba-

\footnotetext{
z 8 marca 1950 r. - Instrukcja o trybie postępowania władz i urzędów bezpieczeństwa publicznego w sprawach odszkodowań i emerytur; zarządzenie nr 061 ministra bezpieczeństwa publicznego z 23 X $1951 \mathrm{r}$. dotyczące trybu postępowania w sprawach o zaopatrzenie emerytalne funkcjonariuszy bezpieczeństwa publicznego; dekret z 27 VII 1955 r. o zaopatrzeniu emerytalnym funkcjonariuszy organów bezpieczeństwa publicznego oraz ich rodzin (Dz. U., nr 31, poz. 184; zmieniony 28 III 1958, uchylony 31 I 1959); dekret z 9 XI 1955 r. o zaopatrzeniu emerytalnym funkcjonariuszy Milicji Obywatelskiej i Służby Więziennej oraz ich rodzin (Dz. U., nr 43, poz. 273; zmieniony 28 III 1958, uchylony 31 I 1959); dekret z 18 IX 1954 r. o zaopatrzeniu emerytalnym generałów (admirałów), oficerów zawodowych i podoficerów nadterminowych oraz ich rodzin (Dz. U., nr 41, poz. 181; uchylony 13 XII 1957); zarządzenie ministrów bezpieczeństwa publicznego oraz pracy i opieki społecznej w sprawie ustalania i wypłaty zaopatrzeń emerytalnych generałów, oficerów zawodowych i podoficerów nadterminowych Wojsk Wewnętrznych oraz ich Rodzin („Monitor Polski”, nr 115, poz. 1645); A. Kochański, dz. cyt., s. 178, 317, 408, 579, 592, 543, 550.

${ }^{42}$ Z. Radzimowski, System finansowy ubezpieczeń społecznych, w: Rozwój ubezpieczeń..., s. 264.

${ }^{43}$ L. Mackiewicz-Golnik, dz. cyt., s. 100-101.

${ }^{44}$ AAN, Ministerstwo Pracy i Opieki Społecznej (dalej: MPiOS), sygn. 171, Minister Pracy i Opieki Społecznej do ob. Prezesa NIK, Warszawa, 16 IX 1950 r., k. 64 i n.

${ }^{45}$ AAN, MPiOS, sygn. 171, NIK do Ministra Pracy i Opieki Społecznej, Warszawa, 5 VIII 1950 r., k. 23; zob. też AAN, Zakład Ubezpieczeń Społecznych (dalej: ZUS), sygn. 3/81, Sprawozdanie z działalności Wydziału Kontroli ZUS za rok 1950, k. nlb.
} 
wione obywatelstwa polskiego. Niezależnie od pozostawania w Polsce i ewentualnego wykonywania pracy, skutkującego obowiązkiem ubezpieczenia - nie mieli oni prawa do żadnych świadczeń z tytułu ubezpieczeń społecznych. Ustanie prawa do świadczeń ubezpieczeniowych następowało $\mathrm{z}$ dniem uprawomocnienia się decyzji władz administracyjnych, a w przypadku skorzystania $\mathrm{z}$ odwołania do sądu $-\mathrm{z}$ dniem zapadnięcia postanowienia sądu, zatwierdzającego zaskarżoną decyzję ${ }^{46}$.

Zgodnie z postanowieniem dekretu z 22 X 1947 r. o dopuszczalności rehabilitacji osób, które były zatrudnione w policji państwowej (tzw. granatowej) i straży więziennej w czasie okupacji niemieckiej (Dz. U., $\mathrm{nr} 65$, poz. 385), osoby te mogły zachować prawo do pobierania zaopatrzenia z funduszów państwowych tylko wtedy, jeżeli poddały się postępowaniu rehabilitacyjnemu przed komisja rehabilitacyjna, powołana przez prezesa Rady Ministrów i zostały zrehabilitowane ${ }^{47}$.

Kolejna grupa dyskryminowaną w zakresie ubezpieczeń społecznych byli Niemcy. Okólnik ZUS z 23 V 1947 r. stanowił, że osoby narodowości niemieckiej $\mathrm{z}$ chwila zatrudnienia $\mathrm{w}$ Polsce podlegały obowiązkowi ubezpieczeń w pełnym zakresie. Tym z nich, którzy mieli tzw. zielone zaświadczenia (Niemcy - fachowcy), udzielano w razie wypadku losowego wszystkich świadczeń przewidzianych w ubezpieczeniu dla ludności polskiej. Ci, którzy tych zaświadczeń nie posiadali, korzystali tylko z ograniczonego zestawu ubezpieczeń. Przy ocenie obowiązu ubezpieczenia, względnie prawa do świadczeń, nie brano pod uwagę okresów ubezpieczenia w niemieckich instytucjach ubezpieczeniowych, jak również nie wypłacano rent przyznanych przez te instytucje ${ }^{48}$.

Zdecydowana zmianę $\mathrm{w}$ tym zakresie przyniosło zarządzenie ministra pracy i opieki społecznej z 21 II 1950 r. o stosowaniu przepisów prawodawstwa społecznego do osób narodowości niemieckiej zamieszkałych w Polsce. Zgodnie z nim wobec pracowników tej narodowości należało odtąd „stosować w całej rozciagłości przepisy polskiego prawa o ubezpieczeniu społecznym, w szczególności w zakresie obowiązku ubezpieczenia oraz świadczeń ubezpieczeniowych"49.

${ }^{46}$ AAN, MPiOS, sygn. 187, ZUS do PUR Zarząd Centralny Łódź, 30 VI 1949 r., k. 290.

${ }^{47}$ Komunikat, „Emeryt” 1947, nr 24.

${ }^{48}$ Okólnik z 23 maja 1947 ZUS $w$ sprawie ubezpieczenia osób narodowości niemieckiej, w: Niemcy w Polsce 1945-1950. Wybór dokumentów, red. W. Borodziej, H. Lemberg, t. 1, Warszawa 2000, s. 284-285.

${ }^{49}$ AAN, MPiOS, sygn. 202, Zarządzenie Ministra Pracy i Opieki Społecznej z 21 II 1950 r. o stosowaniu przepisów prawodawstwa społecznego do osób narodowości niemieckiej, zamieszkałych w Polsce, k. 276. 
Wreszcie przejawem stalinizacji w systemie ubezpieczeń społecznych było powołanie w lipcu 1949 r. działającej do marca 1954 r. Komisji Weryfikacyjnej zajmującej się weryfikacja zaopatrzenia osób, które przed 1 IX 1939 r. „uprawiały lub popierały działalność antydemokratyczną lub działalność przyczyniającą się do faszyzacji życia w Polsce" 50 .

Tak samo należy ocenić zmianę wspomnianej ustawy z 23 VII 1945 r. o zasiłkach i pomocy dla osób pozostałych po uczestnikach ruchu podziemnego i partyzanckiego, poległych w walce o wyzwolenie Polski spod najazdu hitlerowskiego, dokonaną dekretem z 26 X 1949 r. W 1950 r. na jego podstawie dokonano weryfikacji wcześniej przyznanych już zasiłków, ograniczając je do osób „pozostających po uczestnikach demokratycznego ruchu podziemnego lub partyzanckiego, którzy ponieśli śmierć w związku z walką o wyzwolenie Polski i zabezpieczenie w niej władzy ludowej”. Faktycznie oznaczało to ograniczenie grupy uprawnionych do ścisłego kręgu ugrupowań i oddziałów komunistycznych ${ }^{51}$.

System ubezpieczeń społecznych został poddany krytyce na II Zjeździe PZPR w lutym 1954 r. Paradoksalnie, jako remedium na jego niedogodności, próbowano stosować (ze znacznym opóźnieniem) wzory sowieckie. Przede wszystkim nastapiła likwidacja ZUS na podstawie dekretu z 2 II 1955 r. i rozbicie organizacji ubezpieczeń społecznych na dwa piony: związkowy i państwowy. Związkom zawodowym przekazano ubezpieczenia społeczne $z$ wyjątkiem spraw dotyczących rent i emerytów. W pionie związkowym powołano Generalny Zarząd Ubezpieczeń Społecznych przy Centralnej Radzie Związków Zawodowych oraz działające w pierwszej instancji wojewódzkie zarządy ubezpieczeń społecznych przy Wojewódzkich Komisjach Związków Zawodowych. Instancjami odwoławczymi uczyniono branżowe zarządy okręgowe związków zawodowych. Wyłączono w tych sprawach drogę postępowania przed sądami ubezpieczeń społecznych. W każdym województwie działało więc kilkanaście nieskoordynowanych instancji odwoławczych.

W pionie państwowym kompetencje ZUS przekazano organom administracji ogólnej i w pierwszej instancji właściwe były wydziały rent Prezydiów Wojewódzkich Rad Narodowych. Ich decyzje podlegały zaskarżeniu do okręgowych sądów ubezpieczeń społecznych i Trybunału Ubezpieczeń Społecznych. Ten system organizacyjny przetrwał do 1960 r., kiedy powrócono do ZUS jako agencji rządowej ${ }^{52}$.

${ }^{50}$ A. Kochański, dz. cyt., s. 106.

${ }^{51}$ AAN, KC PZPR, sygn. 237/XXVII-36, MPiOS, Zarząd Rent do KC PZPR Wydział Historii Partii, Warszawa, 27 II 1957 r., k. 24.

${ }^{52}$ C. Jackowiak, dz. cyt., s. 224; E. Borowczyk, dz. cyt., s. 250-251; T. Inglot, Welfare States in East Central Europe, New York 2008, s. 94. 
Istotne przemiany w zakresie wysokości i sposobu naliczania świadczeń emerytalno-rentowych rozpoczęły się z chwila wydania dekretu z 25 VI 1954 r. (Dz. U., nr 30, poz. 116). Od 1 lipca tego roku zniesione zostały m.in. odrębne systemy zaopatrzenia emerytalnego i wypadkowego dla pracowników fizycznych i umysłowych oraz odrębne zaopatrzenia dla pracowników publiczno-prawnych; mimo to nadal na początku 1957 r. istniało jedenaście różnych systemów emerytalnych.

Dekret z 1954 r. przewidywał trzy rodzaje rent: starcze, inwalidzkie (podzielone na trzy grupy, o przynależności do których decydowały komisje inwalidztwa i zatrudnienia) ${ }^{53}$ i rodzinne oraz dla pracowników. Wydzielono dwie kategorie pracowników. Do pierwszej zaliczono zatrudnionych pod ziemią i w warunkach szkodliwych dla zdrowia, którym przyznano korzystniejsze uprawnienia rentowe, do drugiej wszystkich pozostałych ${ }^{54}$. Ujemną stroną dekretu był podział rencistów na dwa portfele: rencistów dawnych i nowych ${ }^{55}$. Prawo do nowych rent przysługiwało tylko tym spośród nich, którzy zgłosili odpowiedni wniosek po 1 VII 1954 r. ${ }^{56}$ Ówczesne władze tłumaczyły zastosowanie

${ }^{53} \mathrm{O}$ ich działalności zob. AAN, KC PZPR, 237/XIV-211, mkf B-58526, Informacja ZUS dotycząca działalności pionu orzecznictwa inwalidzkiego, Warszawa, luty $1962 \mathrm{r}$., k. 57.

${ }^{54}$ Pierwsza kategoria została znacznie poszerzona w nowelizacji dekretu z $1958 \mathrm{r}$. Objęto nią nauczycieli, pracowników zatrudnionych na statkach morskich w żegludze międzynarodowej i żegludze powietrznej.

${ }^{55}$ Pierwszy podział na stary i nowy portfel świadczeń został zastosowany w 1949 r., kiedy to zróżnicowano ryczałtowe renty w zależności od tego, czy uprawniony do nich przepracował co najmniej 18 miesięcy w powojennej Polsce; zob. H. Pławucka, dz. cyt., s. 384-387.

${ }^{56}$ Przeciwko takiemu rozwiązaniu protestowały zwiąki emeryckie; zob. m.in. AAN, KC PZPR, sygn. 237/XXVII-36, Komisja Porozumiewawcza Zarządów Głównych Związków Emerytów, Inwalidów i Rencistów do KC PZPR, Warszawa, 11 VIII 1958 r., k. 29-29v; AAN, KC PZPR, sygn. 237/XXVII-30, Memoriał opracowany przez Prezydium Centralnej Rady Związków Emerytów Inwalidów i Rencistów w sprawie uwzględnienia przy uchwalaniu budżetu na rok 1958 najniezbędniejszych postulatów milionowej masy osób pobierających renty, k. 4-14. Świadomość tego niezadowolenia i jego zasadności miały struktury władzy, o czym świadczy zachowana w aktach KC PZPR notatka z 24 III 1956 r., analizująca „luki i wątpliwości” dotyczące dekretu z czerwca 1954 r. Wynika z niej, że oprócz stworzenia starego i nowego portfela rent za wątpliwe uznano rozwiązanie, które dotyczyło uzyskania renty starczej przed 65. rokiem życia przez osoby z dużym stażem pracy. Możliwość taka została stworzona w przypadku, gdy osoby ubiegające miały 25-letni staż pracy (kobiety - 20-letni) i jednocześnie osiagnęły wiek 65 lat (kobiety - 60). W praktyce oznaczało to, że prawo do renty starczej uzyskiwały w jednakowym czasie (po osiagnieciu 65 lat) zarówno osoby z 25-letnim, jak i 45-letnim stażem pracy; zob. AAN, KC PZPR, sygn. 237/XXVII-26, Notatka w sprawie zaopatrzeń emerytalnych, 24 III 1956 r., k. 44 i n. 
takiego rozwiązania zbyt dużym kosztem „przeniesienia dawnego portfela na nowy" - starych rencistów było w 1954 r. około 900 tys. Dla złagodzenia tej słabości systemu Rada Ministrów dokonała podwyżek świadczeń: od 1 VII $1954 \mathrm{r}$. przez podwyższenie rent pracowniczych o 20 zł i rent wdowich o 10 zł oraz od 1 VII 1956 r. przez podwyższenie dodatków dla rencistów niepracujacych i nieposiadających dochodów z innych źródeł - do kwoty 260 zł.

1 VII 1956 r. wprowadzono nowelizację dekretu. Zniosła ona m.in. górną granicę podstawy wymiaru renty (1200 zł), dała pracownikowi względnie jego rodzinie prawa wyboru okresów, z których zarobki mogły być brane za podstawę jej wymiaru. Nastapiło podwyższenie renty rodzinnej w przypadku, gdy członek rodziny był inwalidą bezradnym lub sierotą zupełna oraz wypłata dodatków w wysokości 50\% renty dla rencistów niepracujacych i nieposiadających innych dochodów. Ponadto nowela przewidywała zaliczenie rencistom - pracownikom publiczno-prawnym i zawodowym wojskowym - lat pracy w okresie okupacji, okresów niewoli i pobytu w obozach pracy przymusowej oraz $\mathrm{w}$ obozach koncentracyjnych, przywrócenie prawa do zaopatrzenia emerytalnego utraconego na podstawie przepisów o weryfikacji lub rehabilitacji po 1949 r. oraz przyznanie renty z dekretu pracownikom, którzy pobierali renty na podstawie dawnych przepisów, a byli ociemniali lub przepracowali po wyzwoleniu co najmniej 10 lat i w okresie pobierania renty nie pracowali. Według informacji przedstawionej sejmowej Komisji Pracy i Opieki Społecznej 15 III 1957 r. przeciętna wysokość rent ze starego portfela na 1 VII 1954 r. wynosiła 178,43 zł, 1 VII 1956 r. - 192,69 zł, 1 II 1957 r. - 239,03 zł, podczas gdy przeciętna wysokość renty górniczej inwalidy (starca) wynosiła na początku 1957 r. $774 \mathrm{zł}^{57}$.

Do 1 VII 1954 r. w zakresie rent dla inwalidów wojennych i wojskowych obowiązywała ustawa z 1932 r., a renty przeciętne wynosiły $75 \mathrm{zł}$ miesięcznie dla inwalidów, około $40 \mathrm{zł}$ dla wdów, 18 zł miesięcznie dla rodziców. W myśl nowej ustawy z 1956 r. nastapiło podwyższenie wymiaru do $500 \mathrm{zł}$, a dla inwalidów I grupy - do $1200 \mathrm{zł}$.

Zmianom uległa również sytuacja osób otrzymujących renty zagraniczne; ich liczba wynosiła w 1956 r. ponad 16 tys. osób. 11 II 1957 r. Narodowy Bank Polski wprowadził nowy, korzystniejszy przelicznik dla tych rent. Na przykład renta francuska, która do tego czasu była

${ }^{57}$ AAN, Kancelaria Sejmu (dalej: KS), sygn. 146, Informacja dla Sejmowej Komisji Pracy i Opieki Społecznej przedstawiona na posiedzeniu Komisji w dniu 15 III 1957 r., k. 46. 
wypłacana w wysokości 561,05 zł miesięcznie, od lutego 1957 r. wynosiła $959,28 \mathrm{zł}^{58}$.

Jako symptom politycznej odwilży i uregulowania zaszłości z okresu stalinizmu należy potraktować instrukcję ministra pracy i opieki społecznej z 4 IX 1954 r. w sprawie weryfikacji praw emerytalnych, naruszonych wspomniana ustawa, powołujacca do życia Komisje Weryfikacyjne $^{59}$ oraz dwa rozporządzenia Rady Ministrów z 1 XII 1956 r.: w sprawie świadczeń rentowych dla osób niesłusznie pozbawionych wolności (Dz. U., nr 59, poz. 279), które stanowiło wykonanie zapisu art. 100 dekretu z 25 VI $1954 \mathrm{r}^{60}$, oraz w sprawie zasad i trybu przywracania praw emerytalnych utraconych na podstawie przepisów o weryfikacji lub rehabilitacji (Dz. U., nr 59, poz. 278). Ustawą z 15 XI 1956 r. (Dz. U., nr 56, poz. 255) podwyższono i przywrócono zaopatrzenia dla osób pozostałych po poległych w walce uczestnikach ruchu podziemnego i partyzanckiego o wyzwolenie Polski spod najazdu hitlerowskiego.

Żądania zmian w zasadach systemu rentowo-emerytalnego ukształtowanego $\mathrm{w}$ okresie stalinizmu były jednymi z postulatów robotniczych pojawiających się $\mathrm{w}$ trakcie strajków robotniczych w początkowym okresie rządów Władysława Gomułki. Postulat przyznawania emerytury po ukończeniu 50. roku życia wysunęli górnicy kopalni soli w Wieliczce w sierpniu 1957 r. ${ }^{61}$ Strajkujacy w Zakładach Przemysłu Spirytusowego w Warszawie żądali m.in. przyznania emerytom deputatu wódczanego i węglowego ${ }^{62}$. Postulaty rozszerzenia uprawnień emerytalno-rentowych wysuwały również środowiska kombatanckie ${ }^{63}$ i emeryckie.

Niezadowolenie społeczne wywołane systemem ubezpieczeń próbowała osłabić ustawa z 28 III 1958 r. o zmianie przepisów o rentach i zaopatrzeniach (Dz. U., nr 21, poz. 93). Przede wszystkim usiłowano złagodzić podział na stary i nowy portfel, ale nie zdołano usunąć wszystkich różnic. Podstawa wymiaru rent dawnych została jedynie częściowo zrewaloryzowana. Wtedy jednak, ze względu na pojawiające się

${ }^{58}$ Tamże, k. 41-52; C. Jackowiak, dz. cyt., s. 225-226.

${ }^{59}$ A. Kochański, dz. cyt., s. 542.

${ }^{60}$ Świadczenia rentowe dla osób niestusznie pozbawionych wolności, „Przegląd Ubezpieczeń Społecznych” 1957, nr 2, s. 53.

${ }^{61}$ Archiwum Instytutu Pamięci Narodowej, Ministerstwo Spraw Wewnętrznych, sygn. II/1078 (121/13), [Informacje o sytuacji strajkowej, woj. Kraków 1957], k. nlb.

${ }^{62}$ Tamże, sygn. II/1080, Informacja dotycząca strajku na terenie Warszawskich Zakładów Przemysłu Spirytusowego w Warszawie przy ul. Ząbkowskiej 27/29/31 w dniu 11 IX 1958 r., k. nlb.

${ }^{63}$ Zob. m.in. AAN, KC PZPR, sygn. 237/XXVII-36, ZBoWiD Oddział Katowice do tow. Ochaba Sekretarza KC PZPR, Katowice, 12 IV 1957 r., k. 10. 
lokalnie bezrobocie, po raz pierwszy wprowadzono ograniczenie łączenia pracy $\mathrm{z}$ emerytura, wykluczając kontynuowanie pracy na pełnym etacie pod groźbą zawieszenia prawa do świadczeń. Zasadę tę utrzymywały kolejno ukazujące się przepisy $\mathrm{w}$ sprawie łączenia pracy $\mathrm{z}$ emerytura. Dla emerytów zatrudnionych w niepełnym wymiarze czasu lub dorywczo wprowadzono barierę dopuszczalnej wysokości wynagrodzeń miesięcznych. Jej przekroczenie powodowało zmniejszenie lub zawieszenie emerytury.

Przyjęte rozwiązania utraciły szybko jednolity charakter, zaczęto wprowadzać wyjątki od tych reguł, obejmujacce kolejne kategorie pracowników, na które istniało szczególne zapotrzebowanie. I tak m.in. 19 I 1957 r. przyjęto dekret określający specjalne uprawnienia dla kolejarzy i ich rodzin (Dz. U., nr 8, poz. 27; zmieniony 29 V 1957 i 2 VII 1958 r.), potwierdzajacy specjalne uprawnienia zawarte w rozporządzeniu Rady Ministrów z 25 VII 1946 r. 28 V 1957 r. przyjęto ustawowa regulację w sprawie uprawnień rentowych górników (Dz. U., nr 32, poz. 139), wcześniej zapisanych w 1951 r. w tzw. Karcie górnika. Tzw. Karta nauczyciela została ustanowiona ustawą z 27 IV 1956 r. (Dz. U., nr 12, poz. 63; zmieniona 28 III 1958 r.).

Innym sposobem różnicowania wysokości świadczeń był występujący w ustawach z 1954 i 1958 r. system dodatków do rent i emerytur, przede wszystkim z tytułu uhonorowania takimi orderami jak: Budowniczy Polski Ludowej ${ }^{64}$, Krzyż Grunwaldu, Virtuti Militari, Odrodzenia Polski, Sztandar Pracy (25\% jej miesięcznego wymiaru), jak i niektórymi tytułami honorowymi. Dodatek $50 \%$ do renty dla pracowników naukowych wprowadzono w $1954 \mathrm{r}$. W ten sposób komplikowano system ubezpieczeń i podporządkowywano go zmieniającym się, bieżącym celom politycznym władz partyjnych i państwowych.

\section{Sytuacja materialna emerytów i rencistów}

Jak zmiany powojenne w systemie ubezpieczeń wpływały na poziom życia emerytów? Podstawowe informacje dotyczace dynamiki liczby i wysokości rent i emerytur w latach 1945-1958 zostały zebrane w tabeli 2 .

${ }^{64}$ Do 1956 r. orderami Budowniczych Polski Ludowej uhonorowano 27 osób. Jego pierwszymi kawalerami (w 1949 r.) byli: Franciszek Aprias, Ksawery Dunikowski, Franciszek Fiedler, Wanda Gościmińska, Stanisław Mazur, Wincenty Pstrowski (pośmiertnie) i Karol Świerczewski (pośmiertnie). Do końca 1977 r. uhonorowano nim 223 osoby; zob. AAN, KC PZPR, sygn. XIA/831, Wykaz osób odznaczonych orderem Budowniczych Polski Ludowej. 
Tabela 2. Renty i emerytury w latach 1945-1958

\begin{tabular}{|c|c|c|c|c|c|c|c|c|c|c|c|c|c|c|}
\hline Wyszczególnienie & 1945 & 1946 & 1947 & 1948 & 1949 & 1950 & 1951 & 1952 & 1953 & 1954 & 1955 & 1956 & 1957 & 1958 \\
\hline $\begin{array}{l}\text { Przeciętna liczba } \\
\text { rent i emerytur } \\
\text { w tys. }{ }^{\text {a }}\end{array}$ & 410 & 529 & $691^{\mathrm{b}}$ & 845 & 948 & 987 & 1049 & 1111 & 1152 & 1097,4 & $1209^{c}$ & $1231^{\mathrm{d}}$ & $1242^{\mathrm{e}}$ & 1224 \\
\hline $\begin{array}{l}\text { W tym emerytury } \\
\text { (renty starcze) }\end{array}$ & - & - & 194,185 & 241,735 & - & - & - & - & - & - & - & - & - & - \\
\hline $\begin{array}{l}\text { Przeciętna mie- } \\
\text { sięczna wysokość } \\
\text { renty i emerytury } \\
\text { bieżącej w zł }\end{array}$ & - & 840 & 2145 & 2515 & - & 97 & 100 & 107 & 162 & 177 & 193 & 226 & 314 & 443 \\
\hline $\begin{array}{l}\text { Przeciętna wysokość } \\
\text { emerytury }\end{array}$ & - & - & - & - & - & - & - & - & - & - & 277 & - & - & - \\
\hline $\begin{array}{l}\text { Przeciętna } \\
\text { płaca w gospodarce } \\
\text { uspołecznionej netto }\end{array}$ & - & - & - & - & - & 558 & 604 & 653 & 918 & 976 & 1020 & 1130 & 1306 & 1392 \\
\hline $\begin{array}{l}\text { Stosunek przeciętnej } \\
\text { płacy do przeciętnej } \\
\text { renty i emerytury }\end{array}$ & - & - & - & - & - & 17,4 & 16,6 & 16,4 & 17,6 & 18,1 & 18,9 & 20,0 & 24,0 & 31,8 \\
\hline
\end{tabular}

a przeciętna liczba rent (emerytur) jest większa niż liczba osób je pobierających gdyż jedna osoba mogła pobierać więcej niż jedno świadczenie; liczba pobierających renty w 1945 r. miała wynosić 187,7 tys., 1946 - 308,9 tys., 1947 - 452,1 tys., 1948 - 564,6 tys., 1949 - 616,5 tys., 1950 - 668,6 tys., 1951 - 705,7 tys., 1952 - 738, 1 tys., 1954 - 780,8 tys., $1954-807,2$ tys.

${ }^{\mathrm{b}}$ wg innych danych osoby pobierające renty i zaopatrzenia w 1947 r. to przeciętnie 375,9 tys., w tym w ubezpieczeniu emerytalnym robotników - 276,5 tys., pracowników umysłowych - 33,1 tys., od wypadków - 66,3 tys.

c wg innych danych - 1105 tys., w tym z Karty górnika 26614

d wg innych danych - 117 tys., w tym stary portfel (renty z dawnych ustaw) - 781,7 tys., z Karty górnika - 29,5 tys.

e wg innych danych 1122,3 tys., w tym stary portfel (renty z dawnych ustaw) - 711,3 tys., z Karty górnika - 33,5 tys.

Źródło: Rocznik statystyczny 1969, Warszawa 1970, s. 536, tabl. 4(840), s. 544, tabl. 7(854); Rocznik statystyczny ubezpieczeń społecznych 1946-1985, Warszawa 1987, s. 34-35, tabl. 2(35); Rocznik statystyczny 1948, Warszawa 1949, s. 193, tabl. 6; Rocznik statystyczny 1957, Warszawa 1957, s. 285, tabl. 16(309); Rocznik statystyczny 1949, Warszawa 1950, s. 143-144, tabl. 17, s. 147, tabl. 26; W. Szubert, Badania nad spoteczna rola rent ubezpieczeniowych, „Studia i Materiały z Historii Ubezpieczeń Społecznych w Polsce” 1985, z. 3, s. 72; L. Mackiewicz-Golnik, Powszechne ubezpieczenie emerytalne. Aspekty ekonomiczne i problemy finansowania, Warszawa 1983, s. 27-31; Rocznik statystyczny pracy 1945-1968, Warszawa 1970, s. 412-413, tabl. 5(147), s. 485, tabl. 6(197), s. 487, tabl. 7(198); T. Gortat, Linia rozwojowa świadczeń rentowych 1955-1965, „Praca i Zabezpieczenie Społeczne” 1966, nr 12, s. 8-9; Statystyka z zakresu ubezpieczeń społecznych, „Przegląd Ubezpieczeń Społecznych” 1948, nr 1-2, s. 47; Ubezpieczenie spoteczne w latach 1944-1954 w liczbach, „Przegląd Ubezpieczeń Społecznych” 1954, nr 7-8, s. 190-195. 
Uwage zwraca gwałtowny, bo blisko trzykrotny (w latach 1946-1958) przyrost liczby rent oraz ponad czterokrotny (w latach 1945-1954) liczby osób je pobierajacych. Uposażenia rentowe wypłacane w latach czterdziestych miały charakter symboliczny, o czym świadczy przede wszystkim ich porównanie z przeciętną płaca netto. Jeżeli uznać, że minimum kosztów egzystencji ustalone pod koniec 1946 r. przez Mieszaną Komisję Płac (organ utworzony uchwałą Komisji Centralnej Związków Zawodowych i Rady Ministrów) wynosiło 6 tys. zł miesięcznie, to okaże się, że przeciętna renta i emerytura wynosiły $14 \%$ tej wielkości. Trudno uznać za pocieszająca konstatację, że owego minimum nie osiagało również $73,7 \%$ ze zbadanych wówczas rodzin robotniczych $^{65}$. Niekompletne dane, jakie udało się zebrać wskazuja, że w pierwszej połowie lat pięćdziesiątych świadczenia emerytalno-rentowe utrzymywały się na niezwykle niskim poziomie, wynoszac od 17,4 (1950) do 18,9\% przeciętnej płacy netto w gospodarce uspołecznionej. Znacząca poprawa tego wskaźnika (do 31,8\%) nastapiła dopiero w związku z reformą emerytalną w $1958 \mathrm{r} .{ }^{66}$

Bardziej szczegółowe badanie emerytur i rent, pozwalające na ich głębszą analizę również pod względem społecznym, zostało dokonane przez GUS w 1956 r., a więc po wydaniu omówionego wcześniej dekretu z 1954 r. o zaopatrzeniu emerytalnym pracowników i ich rodzin, który wszedł w życie 1 lipca tego roku. Średnia wysokość renty starego portfela wynosiła w okresie prowadzenia badania 212,50 zł, z tego renty z ubezpieczenia emerytalnego powszechnego - 191 zł, wypadkowego 141,5 zł, państwowego (cywilne i wojskowe, samorządu terytorialnego, monopoli, lasów państwowych, poczty) - 245,70 zł, brackiego - $285 \mathrm{z}$. Renty do 160 zł stanowiły 41,2\% rent z pracy, w tym 50\% rent emerytalnych powszechnych, $66 \%$ wypadkowych, $33,7 \%$ państwowych i $17 \%$ brackich. Średnia wysokość renty wdowiej to $134,40 \mathrm{zł}$; renty najniższe $\mathrm{w}$ tej grupie, do $110 \mathrm{zł}$, pobierało 60,2\% wdów. Tylko 11,4\% rencistów z tytułu własnej pracy i $0,3 \%$ wdów otrzymywało renty w wysokości ponad 300 zł, co przy stanie rencistów na 30 VI 1956 r. z tytułu własnej pracy - 463 tys. i wdów - 270 tys., stanowiło 191 tys. inwalidów pobierających 160 zł i 163 tys. wdów otrzymujących $110 \mathrm{zł}$.

W nowym portfelu renty $\mathrm{z}$ tytułu pracy własnej w wysokości do 160 zł pobierało około 9\% rencistów (inwalidów i starców). Minimalna

${ }^{65}$ J. Chumiński, Ruch zawodowy w Polsce w warunkach ksztattujacego się systemu totalitarnego 1944-1956, Wrocław 1999, s. 133.

${ }^{66}$ Według ustaleń Tomasza Inglota (dz. cyt., s. 150, tabl. 3.3.) wydatki na renty stanowiły w latach 1947-1947 od 2,5\% (1951) do 4,6\% (1957) funduszu płac, podczas gdy w 1937 r. $-4,9 \%$. 
renta rodzinna dla jednej osoby wynosiła $120 \mathrm{zł}$ i rent takich było $6,5 \%$. Rent w grupie najwyższej, powyżej $300 \mathrm{zł}$ (nowy portfel), było z tytułu własnej pracy $57,6 \%$, rodzinnych - 33,7\%. Podczas gdy przeciętna wysokość rent w starym portfelu z tytułu własnej pracy wynosiła $212,50 \mathrm{zł}$, a wdowiej - 134,40 zł, to w nowym portfelu analogicznie: 343 i $248 \mathrm{zł}$.

Mimo że rent zapewniajacych minimum egzystencji, szacowane wówczas na około 500 zł, było w tym portfelu więcej niż w starym (z tytułu własnej pracy - 1,4\%, wdowich - 0), to i tak było ich bardzo mało, bo tylko $5,6 \%$ i to jedynie $\mathrm{z}$ tytułu własnej pracy. Ponadto duży odsetek tych ostatnich (inwalidzkie III grupy) nie osiagał minimalnej wysokości renty emerytalnej starego portfela.

Ze względu na brak rezerw finansowych podwyżkami rent objęto $\mathrm{w}$ starym portfelu zasadniczo tylko osoby niepracujące i niemające innych źródeł utrzymania (o dochodzie przekraczającym 500 zł), ustalając minimum renty z tytułu własnej pracy na $260 \mathrm{zł}$, a renty wdowiej, względnie kwoty wspólnej sierot zupełnych, na 180 zł. W nowym portfelu podwyższono ogólnie minimalną podstawę wymiaru świadczeń z 400 do 500 zł, przyznano dodatek do renty od zarobków przekraczających 1200 zł (15-20\%), zmieniono wysokość dodatków związanych z podwyżka renty lub zmianą podstawy wymiaru renty (podwyżka dodatków dla pracowników nauki, za odznaczenie orderem, za wypadek przy pracy w rentach rodzinnych) i złagodzono cały szereg przepisów dotyczących prawa do świadczeń.

Cytowane badanie objęło 694175 rencistów starego portfela na ich ogólną liczbę na 30 IX 1956 r. wynoszącą 768 190. Dla 425476 z ogólnej liczby zbadanych, tj. 61,3\%, renta stanowiła jedyne źródło dochodu. Z ogólnej liczby rencistów nowego portfela, wynoszącej 31 XII 1956 r. 179 812, poddano badaniu 139 835, tj. 77,8\%. W ich przypadku jedynie z renty utrzymywało się $47,9 \%$. Odsetek rencistów nowego portfela w wieku ponad 64 lat wyniósł $29,2 \%$, starszych $-49,8 \%$. Średni wiek rencistów nowego portfela to 58,3 lata, starego $-64,4^{67}$.

W 1955 r. średnia renta (193 zł miesięcznie) równała się 39\% wielkości średniego spożycia przypadającego na głowę ludności (500 zł miesięcznie). W 1960 r. wskaźnik ten wzrósł do 78\%. Jeśli uwzględnić, że według badań GUS z jednej renty utrzymywało się 1,4 osoby, to okaże się, że na osobę w rodzinie rencisty przypadało w 1955 r. 28\% średniego spożycia na głowę ludności, w 1960 r. $-55 \%{ }^{68}$.

${ }^{67}$ Struktura rent $w$ 1956, Warszawa 1958, s. 5-15.

${ }^{68}$ AAN, KC PZPR, sygn. 1737, mkf 2896, M. Winiewski, Stan i perspektywy zaopatrzenia emerytalnego w Polsce. Studium, poufne, Warszawa 1967, k. 322 i n. 
Mimo korzystnych zmian w wysokości uposażeń rentowo-emerytalnych, w latach 1945-1958 fakt bycia emerytem lub rencista zwykle oznaczał ogromną degradację materialna. Samodzielne przeżycie w oparciu wyłącznie o emeryturę (rentę) dla ogromnej większości ją pobierających było bardzo trudne, a często wręcz niemożliwe.

Świadectwem tego procesu pauperyzacji w okresie tużpowojennym sa przede wszystkim wyniki unikatowych badań przeprowadzonych na zlecenie Ministerstwa Pracy i Opieki Społecznej przez Polski Instytut Służby Społecznej w Łodzi, przy czynnym współudziale Katedry Polityki Społecznej i Ustawodawstwa Społecznego Uniwersytetu Łódzkiego, w 1948 r. w Warszawie (Ochota - 457 wywiadów) i Łodzi (Chojny 530 wywiadów). Objęły zarówno rencistów, jak i osoby pobierające od przedwojnia tzw. zaopatrzenia (dalej dla uniknięcia komplikacji nazywam obie kategorie rencistami).

Stwierdzono w nich, że szczególnie trudna, wręcz „dramatyczna”, była sytuacja żyjacych samotnie. „Poziom ich bytowania odpowiada nędznej wegetacji, odżywanie jest nad wyraz skromne, najkonieczniejsze potrzeby pozostają bez zaspokojenia. [...] Do grupy szczególnie upośledzonej należą również osoby złożone ciężką choroba, ułomne lub dotknięte kalectwem zmuszającym do korzystania ze stałej pomocy lub opieki. Otrzymany przez nie niekiedy tzw. dodatek dla bezradnych nie stoi w żadnej proporcji do zwiększonych potrzeb"69.

W Warszawie na 128 zbadanych mieszkań rencistów 94 były lokalami jednoizbowymi o zaludnieniu na izbę wynoszacym średnio 2,7 osoby, co dawało $5,2 \mathrm{~m}^{2}$ na osobę. W Łodzi na 321 zbadanych mieszkań było 250 jednoizbowych; odpowiednie wskaźniki osób na izbę wynosiły średnio 2,1 , a powierzchni $-7,8 \mathrm{~m}^{2}$ na osobę ${ }^{70}$.

O skali trudności, z jakimi musieli się borykać w swej codziennej egzystencji świadczą również listy emerytów do władz państwowych i radia. Ciekawe informacje na ten temat można odnaleźć także w publicystyce prasowej, szczególnie z lat 1945-1949 i z okresu odwilży politycznej 1955-1957.

I tak np. w kwietniu 1947 r. w periodyku „Emeryt”, wydawanym przez Okręgowy Związek Emerytów Państwowych w Poznaniu, pisano, jak trudno było utrzymać się rodzinom pobierającym nawet podwyższone wówczas (do 2 tys. zł) uposażenia. Posłużono się w tym celu listem wysłanym do redakcji z Gdyni, zawierajacym informacje o kosztach

${ }^{69}$ W. Szubert, Badania ..., s. 106.

${ }^{70}$ Tenże, Renciści ubezpieczenia emerytalnego robotników $w$ świetle badan $z$ roku 1948, „Studia i Materiały z Historii Ubezpieczeń Społecznych w Polsce” 1987, nr 5, s. 129. 
utrzymania dwóch osób, tj. emeryta z żona. Wyliczenie zawierało następujące pozycje: komorne (1 pokój z używalnością kuchni) - $200 \mathrm{zł}$, świadczenia lokatora (woda, gaz, stróż, kominiarz itp.) - 200 zł, opał - 250 zł, światło - 100 zł; wyżywienie (,życie"): chleb - 480 zł, zupa kartoflowa (30 x 2) - $1800 \mathrm{zl}$, namiastka herbaty - $200 \mathrm{zl}$, cukier $2 \mathrm{~kg}$ - 360 zł, pranie -500 zł, mydło - 100 zł, nici, bawełna, igły - 100 zł, lekarstwa - 200 zł, zapałki - 90 zł, fryzjer i inne drobne wydatki 75 zł. Razem - 4555 zł. „Redakcja - podsumowano to wyliczenie przeprasza Szan[ownego] Autora, że skreśliła z Jego rachunku pozycje wydatków na papierosy i na gazetę, uważa bowiem, że emeryt nie musi ani palić ani czytać gazet"71.

Ten charakterystyczny sposób przedstawiania swych racji, polegający na szczegółowym wyliczaniu własnych budżetów, mający przekonać adresatów tych listów do racji nadawców był stosowany powszechnie zarówno wtedy, jak i potem.

W okresie stalinowskim z przyczyn oczywistych prasa nie przedstawiała głosów krytycznych na temat materialnych warunków życia emerytów. Wątek ten obecny był jednak w listach pisanych do centralnych instytucji państwowych ${ }^{72}$. W 1954 r. najliczniejsza grupa skarg (ponad $60 \%$ wszystkich!) kierowanych do rządu dotyczyła dekretu o powszechnym zaopatrzeniu emerytalnym z tego roku. Piszacy podawali, że cofnięto im uposażenie emerytalne, pobierane od kilku lat, bo nie odpowiadaja oni warunkom przewidzianym $\mathrm{w}$ dekrecie uprawniajacym do zachowania praw emerytalnych (brak wymaganego wieku, trwała niezdolność do pracy, zbyt krótki okres pracy). Skarżono się również na wstrzymanie wypłaty emerytur do czasu wydania orzeczenia inwalidzkiej komisji lekarskiej, która działała opieszale ${ }^{73}$.

Nurt krytyki systemu emerytalnego wyraźnie nasilił się po październiku 1956 r. Jej przedmiotem były nie tylko materialne warunki życia emerytów, ale również sposób przeprowadzenia reformy emerytalnej w 1958 r. Oprócz ustalenia limitu dochodów z pracy (o czym w dalej) niezadowolenie wzbudzało utrwalenie powstałego jeszcze w $1949 \mathrm{r}$. i rozszerzonego w 1954 r. (i wówczas już krytykowanego) ${ }^{74}$ podziału na emerytury i renty nowego i starego portfela. Jak pisali autorzy listów

${ }^{71}$ Listy z kraju. Gdynia, „Emeryt” 1947, nr 8.

${ }^{72}$ Archiwum Dokumentacji Aktowej Telewizji Polskiej SA (dalej: ADA), Komitet ds. Radiofonii Polskie Radio (dalej: KdsR), sygn.1050/9, Biuletyn nr 3, Biuro Listów, 14 I 1954 r., k. nlb.

${ }^{73}$ AAN, KS, sygn. 12, Protokoły Komisji Administracji i Wymiaru Sprawiedliwości, k. 23 i n.

${ }^{74}$ ADA, KdsR, sygn. 1050/20, Biuletyn nr 23 z 6 IV 1957 r., k. nlb. 
zgromadzonych w tajnym biuletynie przeznaczonym dla ludzi władzy: „Traktowanie rencistów jako uciążliwych petentów, którym Państwo wypłaca rentę nie jako należne wynagrodzenie, zdobyte ciężką i długoletnia praca, a raczej $\mathrm{w}$ formie zasiłku, nota bene niewystarczajacego na zaspokojenie elementarnych podstaw życia (360-500 zł), stworzyło w tym środowisku pojęcie »bezużytecznych ludzi wegetujących, materialnie niezabezpieczonych«. Zróżnicowanie uprawnień do rent (tzw. "stary" i "nowy portfel«), odebranie zdobytych uprzednio przywilejów (zniżki kolejowe), oraz nie objęcie "prawem emerytalnym" pewnych grup pracowniczych [...] potęguje bolesne rozgoryczenie wśród większości rencistów”. Tylko w III kwartale 1958 r. na temat rent wpłynęło do Biura Listów Polskiego Radia 1637 skarg, co stanowiło 5,4\% ogółu listów. Najbardziej drastycznym i nierozwiązanym przez nowa ustawę problemem, który wywoływał wiele skarg i protestów, szczególnie wśród tych rencistów, którzy - jak pisali - „mieli nieszczęście” przejść na rentę w 1953 r., był podział na stary i nowy portfel ${ }^{75}$.

Przeciwko tej sytuacji protestowały związki emeryckie. „Memoriał opracowany przez Prezydium Centralnej Rady Związków Emerytów Inwalidów i Rencistów w sprawie uwzględnienia przy uchwalaniu budżetu na rok 1958 najniezbędniejszych postulatów milionowej masy osób pobierajacych renty"76 opisywał ich nastroje w sposób następujący: „wśród emerytów panuje skrajna nędza, masy cierpia głód, który jest złym doradca i rodzi złe nastroje. Najbardziej zainteresowani tym zagadnieniem są emeryci a w szczególności starego portfelu. Wielu z nich mówi, że skrzywdziła ich Partia, Rząd i Sejm. Mówia, że odebrano im nabyte praca całego życia i wywalczone od sanacji prawa emerytalne. Pogarszano te prawa przez 11 lat po odzyskaniu niepodległości. Płynie przez Polskę głos rozpaczy i wołania, że marnowano pieniądze na różne imprezy, festiwale, stacje zagłuszajace, bibułę propagandowa, wyjazdy zagranicę, kupowanie zbędnych maszyn, dawanie pośrednikom przy handlu zagranicznym, tworzenie zbędnych ministerstw, zbędnych urzędów, centralnych zarządów, i wiele wiele innych. [...] Wielu zacina się i milczy. Inni mówią o zagadnieniu i podaja go w indywidualnym naświetleniu i wskazuja, że odpowiedzialność za ten stan, za ich nędze ponosi Partia. Wielu szuka ratunku w pracy lecz pracować nie może - więc żebrze. Emeryci z Warszawy i Piotrkowa Tryb[unalskiego] podjęli inicjatywę odwołania się do towarzystw dobroczynnych w Ameryce o zbieranie datków na głodnych emerytów w Polsce. Ze

${ }^{75}$ ADA, KdsR, sygn. 1050/33, Notatka dotycząca uwag rencistów na temat ustawy emerytalnej z 1 VII 1958 r., k. nlb.

${ }^{76}$ AAN, KC PZPR, sygn. 237/XXVII-30, k. 4-14. 
Śląska i Poznańskiego dochodziły głosy, że ci, którzy służyli w wojsku niemieckim, winni starać się o zwolnienie z obywatelstwa polskiego i winni wyjechać do Niemiec, bo tu sa głodni” (pisownia i interpunkcja oryginalne). Krytykowano nie tylko istniejaccy system degresji i podział na stary i nowy portfel, ale również rażącą różnicę między emeryturami wojskowych, funkcjonariuszy milicji, aparatu bezpieczeństwa, służby więziennej, wynoszącymi $85 \%$ zarobków, a tymi powszechnymi, które $\mathrm{w}$ wielu przypadkach rent z nowego portfela mogły wynosić jedynie $30 \%$ osiaganych zarobków. Jako patologię systemu wskazywano również sytuację, w której przeciętna renta starcza z nowego portfela po wysłużeniu 45 lat wynosiła $444 \mathrm{zł} 47 \mathrm{gr}$, natomiast przeciętna renta inwalidzka po wysłużeniu 5 lat - 412 zł 86 gr., „co zabija u pracownika dążność dosługiwania się rent starczych”.

Jak więc w tych zmieniajacych się, ale trudnych materialnie warunkach radzili sobie emeryci i renciści? Jakie były ich strategie przetrwania?

\section{Emeryckie strategie przetrwania}

O najważniejszej z nich informuje list MJ, wysłany do Polskiego Radia z Nowej Huty w 1956 r. Autor pisał: „Emerytura powinna być zaszczytem i duma wysłużonego za jego pracę ciagłą i uczciwa, powinna zapewniać względnie spokojne ostatnie lata życia. Tymczasem każdy pracownik jak ognia boi się tego słowa, jak śmierci, jak powolnego konania. Starym to spędza sen z powiek i spokój w pracy. W dobie rozkwitu Polski Ludowej to starcy sa ciemna plama, którzy jak wyrzuty sumienia błądza po urzędach i pośrednictwach zatrudnienia, wyciagając rękę po jakąkolwiek pracę, by móc żyć - byle jak żyć"77. Jak widać, dla części przynajmniej starych ludzi praca mimo osiagnięcia wieku emerytalnego była najważniejszym sposobem na złagodzenie drastycznej obniżki standardu życia, nierzadko poniżej minimum egzystencji.

Świadczą o tym m.in. wyniki cytowanych już badań przeprowadzonych w 1948 r. w Warszawie i Łodzi. Ustalono wówczas, że udział pracujących w całej populacji badanych rencistów wynosił w Warszawie $51 \%$, a w Łodzi 39\%, z tego wśród pobierających renty starcze - odpowiednio 56,5 i 55,1\%, a spośród inwalidów - 47 i 11\%. Wśród zawodów, które wykonywali renciści starcy w Warszawie, szczególnie często występowali dozorcy (zwłaszcza wtedy, gdy stan zdrowia nie pozwalał na wykonywanie innych zajęć) i pracownice domowe, w Łodzi - tkacze

${ }^{77}$ ADA, KdsR, sygn. 1050/15, Biuletyn nr 25, 19 IV 1956 r., k. nlb. 
i prządki. Warunki pracy pracownic domowych - jak stwierdzali uczestnicy badań - z reguły były bardzo złe, wręcz upokarzające. Zdarzały się przypadki podejmowania pracy ewidentnie niewskazanej (gruźlik jako kelner, niedowidzący jako szofer!). Oprócz tego dość częste były przypadki pracy nieregularnej, dorywczej (prowadzenie kiosku z papierosami, handel cukierkami w parku itp. ${ }^{78}$. Podsumowując wyniki badań, Wacław Szubert pisał: „Dążenie do utrzymania się w pracy występuje u wszystkich rencistów, którzy jeszcze czują się do niej na siłach nawet przy złym stanie zdrowia i obiektywnie stwierdzonym inwalidztwie. Nie mogąc pracować regularnie, chwytają się zarobków dorywczych, aby tylko uzupełnić dochody do poziomu niezbędnego minimum. [...] Znaczenie renty jest dla nich istotne, ale pomocnicze. Łagodzi ona trudności życiowe, ale nie zwalnia od dalszego wysiłku dla zabezpieczenia podstaw egzystencji. Przy obecnym wymiarze rent trudno oczekiwać, aby renciści mogli powstrzymywać się od pracy"79.

Ten motyw pracy - jako jednej z niewielu dostępnych strategii przetrwania - potwierdzają listy emerytów do Polskiego Radia ${ }^{80}$.

Problem łączenia pobieranych świadczeń rentowo-emerytalnych z pracą wystąpił również $\mathrm{w}$ omawianych wcześniej badaniach GUS z 1956 r. Wśród rencistów pobierajacych różne renty ze starego portfela pracowało $29,9 \%$, a w przypadku nowego portfela - $46,3 \%$, co wynikało z tego, że byli młodsi i łatwiej było im znaleźć pracę. Podczas gdy wśród osób pobierających rentę starczą z nowego portfela było prawie $82 \%$ pracujących zarobkowo, to wśród pobierajacych renty inwalidzkie - 42,2\% (III grupa inwalidzka ${ }^{81}$ ). W konkluzji wyników tych badań stwierdzano: „Renciści starego portfelu [...] zarabiają mało i przejście na rentę [...] nie pociaga ich wcale bo renta nie zapewnia im spokojnej starości. Renciści nowego portfelu uważaja renty za dodatek do niskich zarobków i nie łatwo zrezygnuja z zatrudnienia na rzecz nie wystarczającej renty. W rezultacie około $35 \%$, tj. 345000 rencistów starego i nowego portfelu pracuje" ${ }^{2}$. Ponadto dodawano, że wobec bardzo niewielkiej wysokości rent starego portfela renciści pobierający takie świadczenia nie pracowali tylko wtedy, gdy nie mogli ${ }^{83}$.

${ }^{78}$ W. Szubert, Renciści..., s. 104-116.

${ }^{79}$ Tenże, Badania..., s. 106.

${ }^{80}$ Zob. m.in. ADA, KdsR, 1050/17, Biuletyn nr 54, 8 IX 1956 r., k. nlb.

${ }^{81}$ Zgodnie z przepisami dekretu z $1954 \mathrm{r}$. zaliczano do tej grupy inwalidów, którzy byli zdolni do pracy dorywczej przy skróconym dniu pracy lub w innym niż wykonywany wcześniej zawodzie - „ze znacznym obniżeniem kwalifikacji”.

${ }^{82}$ Struktura rent..., s. 6-23 (pisownia i interpunkcja oryginalne).

${ }^{83}$ Tamże, s. 6. 
Wobec braku materiałów porównawczych trudno zweryfikować ten szacunek. Dużo wcześniej, bo w lipcu 1949 r., wskaźnik pracujących inwalidów miał wynosić 60-70\% i - jak stwierdzono w odpowiednim dokumencie - „każdą ich liczbę może wchłonać rynek pracy” po odpowiednim przeszkoleniu ${ }^{84}$. Wiadomo, że w 1954 r. ZUS określał wskaźnik pracujacych emerytów i rencistów na $30 \%^{85}$. Zatrudnienie pracowników w wieku 60 lat i więcej (poza rolnictwem) miało wówczas wynieść 210 tys. osób, tj. 3,7\% ogółu zatrudnionych ${ }^{86}$. Leon Chajn, podsekretarz stanu w Ministerstwie Pracy i Opieki Społecznej, na posiedzeniu sejmowej Komisji Pracy i Zdrowia w marcu 1955 r. twierdził, że ministerstwo przeprowadziło badania zatrudnienia rencistów w Siemianowicach, Pabianicach i Siedlcach. Wynikało z nich, że tylko 22,4\% utrzymywało się wyłącznie z renty, a $5 \%$ było dorywczo zatrudnionych. Zdecydowana większość pracowała dodatkowo ${ }^{87}$.

Co warto podkreślić, fakt pracy wielu emerytów budził zastrzeżenia i sprzeciw w środowiskach pracowniczych, zagrożonych lokalnym bezrobociem w okresie destalinizacji. To wówczas pojawiły się próby zapewniania miejsc pracy dla poszukujących jej czynnych zawodowo mężczyzn kosztem zwalniania kobiet i emerytów. Świadczy o tym chociażby informacja na temat działalności rad robotniczych w hutnictwie z marca 1957 r. Zapisano w niej m.in., że w hucie „Kościuszko” podejmowane były próby zwolnienia wszystkich emerytów w wieku ponad 70 lat, a kobietom, których mężowie pracuja, „wydano kartki ażeby przyniosły poświadczenie zarobków swych mężów”. Rada wydała nawet polecenie przewodniczącemu Rady Zakładowej, aby przeprowadzał rozmowy z tymi emerytami, na co jednak ten nie wyraził zgody i opuścił posiedzenie rady robotniczej ${ }^{88}$.

Wiadomo, że w 1958 r., według wyników badań Wojciecha Muszalskiego, pracowało 40,5\% emerytów i rencistów, z tego w przedziale wiekowym 65-69 lat - 47,6\%, 70-74-34,7\%, a 75-79-19,2\% 30 IX 1957 r., jak ustaliło Ministerstwo Pracy i Opieki Społecznej, na 969500 rent wypłacanych przez służby mu podległe 332835 pobierali

\footnotetext{
${ }^{84}$ AAN, ZUS, sygn. 23, Notatka, 18 VII 1949 r., k. 41.

${ }^{85}$ AAN, ZUS, sygn. 23, ZUS W[ydział] Statystyki do PKPG, Warszawa, 9 VII 1954 r., k. 1.

${ }^{86}$ J. Staręa, Ludzie starzy a praca zawodowa, Warszawa 1976, s. 31-32.

${ }^{87}$ AAN, KS, sygn. 22, Protokół nr 4 z posiedzenia Komisji Pracy i Zdrowia z 22 III 1955 r., k. 68-69.

${ }^{88}$ Archiwum Ruchu Zawodowego, Centralna Rada Związków Zawodowych, sygn. tymczasowa 189/10, Informacja z działalności Rad Robotniczych ZG Związku Zawodowego Hutników, Katowice, 14 III 1957 r., k. nlb.

${ }^{89}$ W. Muszalski, dz. cyt., s. 158.
} 
pracujacy (34\%); w przypadku rent kolejowych wskaźnik ten wynosił $33 \%{ }^{90}$. Łaczenie pracy zawodowej z rentą stawało się szczególnie częste w niektórych zawodach (przykładem mogą być górnicy) i związane było z relatywnie dużymi zarobkami (ok. 1800-2000 zł w przypadku górników dołowych badanych w 1957 r. $)^{91}$.

Powszechna praktyka łączenia renty inwalidzkiej (zwłaszcza tzw. III grupy) z praca zawodową na takim samym stanowisku co przed przyznaniem owego świadczenia została uznana za patologię systemu ubezpieczeń społecznych w trakcie dyskusji, jaka toczyła się przede wszystkim na łamach czasopism fachowych po październiku $1956 \mathrm{r}$. Julian Łukasiewicz po analizie tego zagadnienia na przykładzie województwa katowickiego pisał: „Słuszniejsze wydaje się odsunięcie od produkcji pracownika niepełnowartościowego, zabezpieczając mu znośnie warunki egzystencji, niż utrzymywać obecną paradoksalną sytuację: pracownik niepełnowartościowy nadal pracuje $\mathrm{z}$ wynagrodzeniem podwyższonym o 30-40 proc., zaś zdrowi i pełnowartościowi pracownicy nie moga znaleźć pracy w ogóle" ${ }^{92}$. Pojawiały się również głosy, że renta inwalidzka III grupy jest wydatkiem niecelowym ${ }^{93}$.

$\mathrm{Na}$ zatrudnienie emerytów i rencistów od końca lat pięćdziesiątych istotny wpływ miały zmiany prawne. W sytuacji, gdy w gospodarce Polski Ludowej pojawiły się trudności z realizacja zasady pełnego zatrudnienia, pracujący $\mathrm{w}$ wieku emerytalnym stanowili grupę, która chciano zmarginalizować. To była najważniejsza przesłanka rozwiązań przyjętych w 1958 r. w ustawie z 28 marca o zmianie przepisów o rentach i zaopatrzeniach (Dz. U., nr 21, poz. 98). Wprowadzono ograniczenie łączenia pracy $\mathrm{z}$ emerytura, wykluczając kontynuowanie pracy na pełnym etacie pod groźbą zawieszenia prawa do świadczeń. Renty nie zawieszano, jeżeli rencista osiagał dochody na podstawie umowy o pracę do 500 zł miesięcznie (wtedy równowartość minimalnej płacy); w przypadku niektórych prac (szczegółowo określonych w rozporządzeniu Rady Ministrów z 6 V 1958 r., Dz. U., nr 26, poz. 111) ta granica zarobków została przesunięta do 750 zł miesięcznie. Niektóre zawody pod tym względem były dodatkowo uprzywilejowane (m.in. nauczyciele mogli bez utraty prawa do pobierania renty osiagać zarobki do

${ }^{90}$ AAN, KC PZPR, sygn. 237/XXVII-32, stan rent w dniu 30 IX 1957 r., k. 62.

${ }^{91} \mathrm{~F}$. Woźniczka, $Z$ badań nad sytuacja zarobkowa rencistów górniczych, „Przegląd Ubezpieczeń Społecznych” 1957, nr 10, s. 275-277.

${ }_{92}$ J. Łukasiewicz, Rozdroża polskiego systemu emerytalnego, „Przegląd Ubezpieczeń Społecznych” 1957, nr 6, s. 166.

${ }^{93} \mathrm{H}$. Balicka-Kozłowska, $W$ sprawie rent dla pracujacych. Czy inwalidztwo jest uprzywilejowaniem, „Przegląd Ubezpieczeń Społecznych” 1957, nr 8-9, s. 239-240. 
1000 zł miesięcznie; pracownicy zakładów społecznych służby zdrowia, zatrudnieni na pełnym etacie, mogli zarabiać bez ograniczeń, z tym że w tym czasie otrzymywali renty odpowiednio zmniejszone) ${ }^{94}$. Jak twierdzi Muszalski, w wyniku zapoczątkowanej wówczas akcji zwalniania osób, które osiagnęły wiek emerytalny, z pracy odeszło 199 tys. emerytów i rencistów oraz innych osób, które „zmuszono przy pomocy różnych środków do wystapienia o przyznanie świadczeń rentowych". Wprowadzone zawieszenie emerytur i rent spowodowało utrate prawa do świadczeń jeszcze w 1958 r. przez około 160 tys. osób, „wśród których musieli się znaleźć przede wszystkim ci, którzy mieli dochody z innych źródeł niż zatrudnienie, ponieważ z pracownikami w większości rozwiąano już stosunek pracy"95.

Wprowadzenie górnej granicy dochodów w wysokości 500 zł dozwolonych zarobków bez zawieszania prawa do renty starczej, pozostawionej na niezmienionym poziomie do 1968 r., przy wzroście płacy minimalnej powodowało, że zarobkowanie emerytów i rencistów stawało się dla nich coraz mniej opłacalne.

Rozwiązania zastosowane w 1958 r. wpłynęły na ograniczenie liczby pracujących emerytów i rencistów. Według danych Narodowego Spisu Powszechnego w $1960 \mathrm{r}$. pracowało 9,8\% z nich ${ }^{96}$.

Wydaje się jednak, że oficjalne dane o zatrudnieniu tylko w części obrazuja problem ich pracy. Niemożliwe jest bowiem oszacowanie „ciemnej liczby” osób, które w różny, nieoficjalny, najpewniej nielegalny czy półlegalny sposób „dorabiały” sobie do niedostatecznych uposażeń.

$\mathrm{W}$ tym trudnym położeniu materialnym często dodatkowe, a czasami jedyne wsparcie stanowiły dzieci i ich rodziny. Już w cytowanych badaniach z 1948 r. stwierdzono, że renta mogła stanowić wówczas jedynie uzupełniające i pomocnicze źródło utrzymania. „Głównym źródłem pozostaje dla większości mężczyzn praca, ci zaś, którzy nie pracuja, opierają się prawie zawsze materialnie o rodzinę. Niewielką rolę odgrywają inne formy dochodów w rodzaju własności, opłat od sublokatorów czy pomocy społecznej. Kobiety utrzymują się natomiast

${ }^{94}$ K. Kolasiński, Pojęcie $i$ charakter prawny zawieszenia prawa do emerytury, Toruń 1971, s. 57-69.

${ }^{95}$ B. Urbaniak, Praca zawodowa po przejściu na emeryturę. Społeczno-ekonomiczne przesłanki powrotu emerytów do aktywnego życia zawodowego, Łódź 1998, s. 188-191; W. Muszalski, dz. cyt., s. 160. Inne dane zob. L. Mackiewicz-Golnik, Funkcje funduszu ubezpieczenia społecznego, Warszawa 1969, s. 103 (autorka podaje, że w 1958 r. jednorazowo odeszło z czynnego rynku pracy ponad 100 tys. pracowników uprawnionych do emerytury, a w latach 1959-1960 „dalsze kilkadziesiąt tysięcy”).

${ }^{96}$ L. Frackiewicz, dz. cyt., s. 32-34. 
przeważnie dzięki zarobkom członków rodziny, nabywając moralne prawo do uczestniczenia w tym dochodzie przez pracę domową dokoła dzieci lub gospodarstwa. Spada na nie z tego tytułu wiele uciążliwych zajęć, pomimo że pozornie uchodzą za "niepracujące«. Renta dołączana jest zwykle do ogólnego budżetu rodziny, wzmacniając pozycję rencistki. Rzadko kiedy stanowi dochód, którym może swobodnie dysponować” ${ }^{\prime}$. W tych warunkach w najtrudniejszej sytuacji pozostawali młodzi inwalidzi, majacy na utrzymaniu dzieci i żony.

Z 209 zbadanych, którzy nie pracowali zarobkowo, 88 zajmowało się prowadzeniem gospodarstwa domowego, 35 pomagało $\mathrm{w}$ prowadzeniu gospodarstwa domowego, 14 sprawowało opiekę nad dziećmi (w tych trzech kategoriach dominowały kobiety), 11 prowadziło ogródek, 9 wykonywało inne zajęcia, 1 osoba żebrała, 50 nie miało określonych zajęć (ponadto 1 przypadek - brak danych). Jako najcięższe prace traktowali wychowywanie wnuczat, prowadzenie gospodarstwa pracującym dzieciom (sprzątanie, gotowanie, dokonywanie zakupów). Renciści niepracujący najczęściej zajmowali się pracą w ogródku. Tym, którzy nie pracowali zawodowo i nie angażowali się w pomoc dzieciom, dzień upływał na wysiadywaniu na podwórku, chodzeniu do kościoła, „po kominkach” i spaniu. Było to „życie smutne i monotonne, ubogie”"

Konieczność zdania się na dzieci z powodu ubóstwa podkreślali również autorzy listów napływających do Polskiego Radia. „Ludzie pytaja się - pisał korespondent „Twardy” w 1956 r. - gdzie jest sumienie Rządu i Partii? Dlaczego się naród oszukuje i starców, którzy przepracowali dla Państwa po 35 lat, skazuje się na śmierć głodowa, lub co gorsza, każe się ich żywić biednym robotnikom i urzędnikom - synom tych emerytów, a pieniądze idą na wspieranie zagranicy, jak Korei, Chin i tym podobne" ${ }^{99}$. O dyskomforcie psychicznym wywołanym taka sytuacja pisała „Emerytka” w liście z 1954 r.: „Piszę ten list w dniu wigilijnym. Mąż mój jest obecnie emerytem w Polsce Ludowej, w której mówi się, że jest troska o człowieka, ale troska jest tylko o dzieci i młodzież. A czy starzy nie byli młodymi i czy nie maja prawa, żeby resztę swych lat przeżyli w minimum egzystencji? Dziś jest wigilia. Panowie Ministrowie, którzy opracowali tak krzywdzące wynagrodzenie dla emerytów, maja dobrze stół zastawiony i cieszą się swoja rodziną. Są syci i nie myślą o tym, czy emeryt z żoną może się utrzymać za 300 zł, lub emerytka za 140 zł. Gdybyśmy nie mieli dzieci,

${ }_{97}$ W. Szubert, Niektóre zagadnienia rent starczych..., s. 38-39.

${ }_{98}$ Tenże, Renciści..., s. 117.

${ }^{99}$ ADA, KdsR, sygn. 1050/17, Biuletyn nr 54, 8 IX 1956 r.; zob. też tamże list słuchaczki z powiatu inowrocławskiego. 
zgłosilibyśmy się do domu starców. Ale kochamy nad życie swoje dzieci i nie możemy się z nimi rozstać. A jednocześnie jesteśmy im ciężarem, bo oboje jesteśmy tak już wyczerpani codziennym niedożywieniem, że osłabieni nie możemy pomagać im w pracy domowej. Dzieci wyjechały na święta, a my w Polsce wyzwolonej głodzimy się, bo co dzieci zostawiły nam $\mathrm{z}$ prowiantu na święta, to my zostawiamy, gdyż jak wróca nie będa miały co jeść, a wiemy, że pieniądze na pewno już wydali. Mąż mój przed wojną otrzymywał 200 zł miesięcznie i za to można było się utrzymać z rodzina. Obecnie emerytura jest powolnym konaniem, to jest wstyd i hańba Polski Ludowej” ${ }^{100}$. W 1951 r. „Emerytka Zofia z Łodzi” apelowała: „Falo 49 powiedz coś o doli biednych emerytów. [...] Gdyż dola nasza jest tragiczna, jeśli ktoś ma dzieci, to może się jeszcze do nich przytulić, ale samotnym jest naprawdę strasznie"101.

Praca i pomoc rodzinie oraz wsparcie z jej strony to najważniejsze strategie przeżycia emerytów i rencistów w tym okresie. Na zupełnym marginesie mieściło się uzyskiwanie pomocy z innej strony w trudnościach codziennego „wiązania końca z końcem”.

W okresie tużpowojennym taka pomoc polegała m.in. na rozdawnictwie darów zagranicznych, zapewnieniu zniżek komunikacyjnych przez władze niektórych miast, sprzedaży niezbędnych artykułów (węgiel, żywność, szkło okienne itp.) po zniżkowych cenach itp. Aktywność na tym polu przejawiały szczególnie emeryckie związki pracowników państwowych ${ }^{102}$. Od listopada 1946 r. z inicjatywy premiera Edwarda Osóbki-Morawskiego i dzięki rządowej dotacji związki emeryckie podjęły próbę utworzenia spółdzielni oszczędnościowo-pożyczkowej „Emera”, która miała się z kolei zajać rozdzielnictwem kredytów na organizację emeryckich spółdzielni pracy ${ }^{103}$. Akcja ta poniosła fiasko, gdyż jak pisano w prasie emeryckiej - zdecydowana większość tych, którzy mogli pracować, już do tego momentu znalazła dla siebie zajęcia ${ }^{104}$.

${ }^{100}$ ADA, KdsR, sygn. 1050/9, Biuletyn nr 3, Biuro Listów, 14 I 1954 r., k. nlb.

${ }^{101}$ ADA, KdsR, sygn. 1050/1, Biuletyn nr 14 Działu Listów i Korespondentów Polskiego Radia, 3 VII 1951 r., k. nlb.

${ }^{102}$ Zob. m.in. AAN, Związek Emerytów Państwowych (dalej: ZEP), sygn. 1/7, Protokół nr 35 z posiedzenia Zarządu Związku Emerytów Państwowych z 19 IX 1945 r. w lokalu przy ul. Targowej $61 \mathrm{~m}$. 20, k. 60; tamże, Protokół nr 50 z posiedzenia ZG ZEP 2 I 1946 r., k. 94; tamże, Protokół z posiedzenia ZG ZEP 18 V 1946 r., k. 132; Sprawozdanie z ogólnego zebrania członków poznańskiego Zwiazku Emerytów Państwowych, Wdów i Sierot, odbytego 22 II 1948 w Sali Akademii Handlowej w Poznaniu, „Emeryt” 1948, nr 5.

${ }^{103}$ Protokót posiedzenia członków Stałej Delegacji Polskich Zrzeszeń Emerytalnych odbytego w Poznaniu 9 i 10 stycznia 1947 r., „Emeryt” 1947, nr 2.

${ }^{104}$ Nasza ankieta, „Emeryt” 1948, nr 4. 
W okresie stalinowskim zwyciężyła koncepcja podporządkowania związków emerytów i rencistów - związkom zawodowym ${ }^{105}$. To stamtąd otrzymywali oni incydentalnie pomoc materialną. Zarówno wtedy, jak i po 1956 r., kiedy odrodził się organizacyjny ruch emerycki, pomoc zwiąkowa była niewielka.

Innym wyjśsiem z trudnej sytuacji, zwłaszcza dla tych najsłabszych, żyjących samotnie, była pomoc ze strony instytucji opieki społecznej. Domy rencisty jednak nie tylko były nieliczne $\mathrm{w}$ stosunku do potrzeb (w 1955 r. było ich 30 o łacznej liczbie miejsc $2520^{106}$, w 1957 r. - 32 z 3104 miejscami ${ }^{107}$ ), ale również sposób funkcjonowania wielu z nich powodował, że traktowano je jako wyjście ostateczne. Jak pisał po wizycie w jednym z nich publicysta „Tygodnika Zachodniego”, pobyt w wieloosobowych pokojach, który był reguła, powodował, że: „Starcza gderliwość, różnica poziomu intelektualnego i materialnego [...] powodują że otwarcie okna, przesunięcie krzesła może stać się przyczyną śmiertelnej kłótni” ${ }^{108}$. Nie znaczy to jednak, że nic się nie zmieniało; wiele nadziei wiazano $\mathrm{z}$ tworzonymi od połowy lat pięćdziesiatych domami dla rencistów z poszczególnych grup zawodowych ${ }^{109}$. Jednak ich ilość i pojemność daleko odbiegały od wzrastających potrzeb.

\section{Konkluzje}

Przedstawione uwagi moga stanowić - zgodnie z tytułem artykułu - jedynie szkic do portretu emerytów i rencistów w latach 1945-1958. Wynika z nich kilka podstawowych wniosków:

1. Emeryci i renciści stanowili grupę społeczna, której liczebność stopniowo wzrastała, jednak mimo to społeczeństwo polskie należało do jednego z najmłodszych w Europie. Zdecydowaną większość osób w wieku poprodukcyjnym (około 70\%) stanowiły kobiety.

2. System ubezpieczeń społecznych stopniowo był pozbawiany autonomii, centralizowany i podporządkowywany realizacji zmieniających się celów partii i państwa. Oznaczało to z jednej strony rozbudowę

${ }^{105}$ Emeryci wstepuja do Zwiazków Zawodowych, „Głos Emeryta i Rencisty” 1949, nr 9-10.

${ }^{106}$ M. Majewska, Państwowe Domy Rencistów, „Przegląd Ubezpieczeń Społecznych" 1956, nr 2, s. 38-39.

${ }^{107}$ AAN, KC PZPR, sygn. 237/XXVII-33, Rozwój zakładów pomocy społecznej, k. 60. W 1957 r. istniało ponadto 165 domów opieki z 12108 miejscami.

${ }^{108}$ R. Danecki, Bezimienne domy Matysiaków, „Tygodnik Zachodni” 1958, nr 23.

${ }^{109}$ W.T., Aktualne problemy opieki społecznej, „Trybuna Ludu” 1958, nr 184. 
i upowszechnienie wielu rodzajów ubezpieczeń (zdrowotne, rodzinne) oraz zrównywanie świadczeń robotniczych i pracowników umysłowych, z drugiej - wypłacanie większości rent i emerytur w wysokości, która nie zapewniała zaspokojenia minimum potrzeb. System ten stworzył nowe grupy uprzywilejowanych i degradowanych ze względu na dostępność i jakość świadczeń, selekcjonowane według kryteriów ideologiczno-politycznych i aktualnych potrzeb gospodarczych.

3. W tej sytuacji, gdy większość rencistów i emerytów nie mogła utrzymać się z wypłacanych świadczeń, najczęściej stosowanymi strategiami przeżycia były praca zawodowa i współzamieszkiwanie z rodzina, połączone zwykle również z wykonywaniem różnych zajęć domowych.

4. To przede wszystkim ciężkie położenie materialne przesądzało o emeryckiej czarnej wizji otaczającej rzeczywistości, obecnej w listach i skargach pisanych do centralnych instytucji partyjnych i państwowych. Gorycz, poczucie krzywdy czy wręcz rozpacz mieszały się w tych listach z krytyka władzy, obarczanej - nierzadko w mocnych słowach - odpowiedzialnością za nędzę ich własnego położenia.

Dariusz Jarosz

Annuitants and Old Age Pensioners in the Polish Social Insurance System 1944-1958. Material Situation and Survival Strategies (Summary)

Annuitants and old age pensioners comprised a social group whose numbers steadily increased in post-war Poland (from almost 187,000 people in 1945 to more than 800,000 in 1954), although Polish society was one of the most recent in Europe. The vast majority of people of retirement age consisted of women (ca. 70\%).

The resurgence of the social insurance system in the post-war period, within its pre-war institutional forms, was gradually deprived of its autonomy, becoming centralised and subjected to the implementation of the Party and the State's changing objectives. Many types of insurance policies (i.e. health, family) were expanded and became more universal, as did bringing insurance for blue-collar workers into line with that for white-collar workers. The employer was now burdened with paying the obligatory insurance dues. The financial independence of the social insurance system was abolished. 1950 ushered in the dominating concept of social insurance in the Polish social security system, which remained in force until 1968, its point of departure being the Law on the Social Insurance Institution (ZUS) passed on 20 July 1950. The law abolished the separate insurance fund by including the insurance budget within the state budget, with ZUS becoming its executor. Health 
care was excluded and was now entrusted to the Employees Health Care Fund Board. Social insurance offices were also closed down. The Law of 29 December 1951 also included in ZUS the National Pension Fund Office, which made payments predominantly to full-time state functionaries and the professional military. This system created new groups of privileged and the degraded, depending on the availability and quality of the services, and selected according to ideological and political criteria and current economic needs. Although the characteristic features of the benefits system binding in the Stalinist period encompassed an increasingly large number of the PRL's population, it did not guarantee the majority of old-age pensioners and annuitants funds which were necessary for maintaining at least a minimum subsistence. The high salary and wage increases in 1954 and 1958 were still not high enough to allow the majority of pensioners and annuitants to meet their basic needs. In this situation, the most frequently used survival strategies involved professional work and sharing accommodation with family members, as a rule combined with the performance of various household chores. This difficult material situation was the prevailing reason for the pessimistic vision of reality reflected in the letters and complaints addressed by old-age pensioners to the central Party and state institutions. Bitterness, a feeling of resentment and, at times, outright despair, was accompanied with criticism of the government which was often accused, in harsh terms, of being responsible for the misery of their daily existence.

Dariusz Jarosz - Instytut Historii PAN; e-mail: darjarosz@wp.pl 